\title{
Do teatro da memória ao laboratório da História: a exposição museológica e o conhecimento histórico
}

\author{
Ulpiano T. Bezerra de Meneses
}

Departamento de História, Faculdade de Filosofia, Letras e Ciências Humanas/ Universidade de São Paulo

1. O teatro da memória

Eilean Hooper-Greenhill (1988), respeitada especialista na educação em museus, sugestionada pela afirmação de Santo Tomás de Aquino, de que o sensivel é o veículo natural do inteligível, pôs-se a examinar, nos relatos sobre as coleções da Renascença, a freqüência com que elas eram designadas como Theatrum Mundi, Theatrum Naturae, Theatrum Sapientiae. A palavra 'teatro', como se sabe, privilegiando a visualidade, conserva sua vinculação etimológica à familia do verbo grego theáomai, ver. Assim, estas coleções de objetos materiais da mais diversa espécie, organizadas pelos príncipes e senhores renascentistas, funcionavam como paradigmas visuais que recriavam simbolicamente a ordem do mundo e o espaço do exercício de seu poder.

Theatrum Memoriae insere-se nessa linhagem, mas enraizando-se, também, nas artes da memória da Antigüidade e da ldade Média, que propunham a articulação de imagens a lugares e espaços, para assegurar a rememoração. Hooper-Greenhill vê aí o surgimento do museu como teatro da memória, conceituação que ela acredita deva ser explorada mesmo hoje, pois seu potencial permaneceu ainda parcialmente inexplorado: é mais eficiente do que a escrita e outros sistemas intermediados de registro já que a matriz 
1. O núcleo original do tratamento dado à problemática da exposição, aqui largamente ampliado e adaptado à especificidade do museu históri$\mathrm{co}$, é um relatório apresentado em 1993 ao Simpósio Internacional "O processo de comunicação em museus de Arqueologia e Etnologia", organizado pelo Museu de Arqueologia e Etnologia - MAE/USP. O relatório, sob o título "A exposição museológica: reflexões sobre pontos críticos na prática contemporânea", foi entregue para publicação em Ciência em museus, mas não tem data assegurada para aparecer. sensorial facilita a rememoração. A partir da seleção mental, ordenamento, registro, interpretação e síntese cognitiva na apresentação visual, ganha-se notável impacto pedagógico.

Esta postura, embora nem sempre formulada com a mesma sofisticação, caracteriza ainda hoje em dia a visão talvez dominante do que seja o museu histórico e quais suas funções.

Na realidade, toda essa formulação é altamente problemática. Primeiro, porque os antecedentes do museu histórico - que se nucleia no século $X V I I I$ e se consolida no século XIX, como se verá mais adiante - são bastante diferentes na Europa e na América la América Latina, inclusive o Brasil, está mais próxima do modelo americano do nortel. A seguir, porque a visão que vai marcar o museu setecentista deriva, sim, do Renascimento, mas é por excelência a visão iluminista - que, na sociedade de consumo, como fruto já temporão, vai desembocar na estetização do social e na transformação da História em espetáculo. Por outro lado, se a formulação deixa de lado traços definidores de funções de evocação e celebração que esses museus continuam a desempenhar, também marginaliza a questão da produção do conhecimento. A memória, igualmente, ficou reduzida a um instrumento de enculturação de paradigmas a priori definidos e que circulam em vetores sensoriais.

Já se vê que o museu histórico contemporâneo apresenta um leque extremamente aberto de problemas, que seria muito difícil tratar aqui, na sua inteireza. Por isso, para garantir um mínimo de eficácia, o que será posto em debate limita-se a dois tópicos básicos, apenas: que possibilidade pode haver de participação do museu histórico na produção do conhecimento histórico? como, nessa perspectiva, funciona a exposição museológica?

O primeiro tópico pressupõe que, por sua natureza mesma, o museu tenha algo a ver com o universo do conhecimento. Isło não significa atrelá-lo exclusivamente a esse universo. Não ignoro as tarefas educacionais do museu Imas se não tiverem como referência o conhecimento, tratar-se-á de mera doutrinação), a fruição estética, o lúdico, o afetivo, o devaneio, o sonho, a mística da comunicação e da comunhão, a curiosidade, a necessidade de mera informação e assim por diante. Muito menos ignoro as responsabilidades sociais - e políticas - do museu histórico. No entanto, estes aspectos todos têm sido debatidos com freqüência, se bem que, a meu ver, de forma superficial e lacunosa. Reconhecer essa gama multiforme de possibilidades é recusar um modelo único de museu, chave da natureza e camisa de força. Portanto, o que aqui se discutirá não é a trilha que todo museu histórico deverá seguir, mas as direções em que ele pode trazer uma contribuição específica le, portanto, insubstituivel), na produção do conhecimento histórico - tema crucial, mas marginalizado nas discussões museológicas.

O segundo tópico limita, aqui, a problemática do conhecimento à exposição museológica'. A formação de coleções, a curadoria e, em suma, a visão integrada do museu como instituição solidariamente científico-documental, cultural e educacional estão fora, pois, do horizonte imediato deste texto. Ora, falar-se de exposição pressupõe, por sua vez, certo perfil de museu lque também não se deve apresentar como uniforme), em que haja pertinência de manter e explorar coleções de objetos materiais. Isto, por sua vez, pressupõe 
considerar a natureza institucional do museu - sem detrimento da importância que se possa atribuir a uma ação extra-muros, a seus aspectos de processo, à importância hierárquica de programas sobre as bases formais, etc.etc.

Estas observações cautelares se justificam por estarem em pauta, no meio museológico, principalmente entre nós, propostas que ou fornecem modelos totalitários tendentes a cancelar a razão de ser do museu qualificado de "tradicional", ou nada têm a dizer a seu respeito, já que admitem apenas "the non-objective status of knowledge and the political inflections to wich it is subject" (Shelton 1995: 111. Pela importância de partir de bases sólidas, conviria, antes de desenvolver os dois tópicos anunciados, clarificar as premissas que os orientam.

\section{Premissas}

Museu e acervo

Modelos como os 'museus comunitários' /desde os neighbourhood museums americanos, como Anacostia, em Washington, até os chamados ecomuseus), trouxeram notável renovação no campo geral da Museologia, em particular quanto a suas responsabilidade sociais. Também serviram de escudo e foram utilizados na produção de algum efeito anestésico quando se simplificaram questões de suma complexidade e gravidade - como o que seria específico do museu, num quadro de ação cultural - para não falar da comunicação de massas e da indústria cultural. Aliás, apresentá-los como uma panacéia ou fórmula imperativa ou, mesmo, ideal, thes retiraria legitimidade política, pois eles deixariam a descoberto uma parcela considerável de necessidades prementes de uma sociedade que é sociedade de classes, predominantemente (e patologicamente) urbanizada e em processo de globalização.

Em maio de 1968, no auge da rebelião estudantil - que logo assumiu feições de movimento social e da França estendeu-se por boa parte do mundo ocidental - dizia-se que era preciso "incendiar o Louvre", então considerado protótipo do almoxarifado de um patrimônio burguês. Funcionando como "templos", os museus apenas homologariam os valores da burguesia. A única alternativa possível seria, assim, substituílos pelos "foruns", espaços da criação, do debate, da interação. Giulio Carlo Argan, por exemplo, propôs que o museu de arte contemporânea, distinto do museu de arte antiga, "histórico" e, portanto, "patrimonialista", dispensasse acervo, para transformar-se num espaço de efervescência criativa. Como se a perspectiva histórica não fosse criativa e como se as funções "documentais" não gerassem democratização, ao ampliar no tempo e no espaço o acesso de um número infinitamente maior de fruidores dessa efervescência; e como se a cidadania pudesse germinar independente da consciência histórica.

Uma década depois, a ingenuidade deste binômio maniqueísta estava patente: o mal não residia no suporte "patrimonial" do museu, pois tanto o templo quanto o forum podiam ser instrumentos altamente conservadores; por sua vez, a dimensão crítica (o próprio nervo do forum) era também capaz de dessacralizar o templo e contribuir para que ele participasse da transformação da sociedade (cf. Cameron 1976). 
Estas considerações levam ao exame de questão trazida à baila, entre nós, com certa reiteração: é possível museu sem acervo?

Creio que a pergunta esteja mal formulada e a polissemia do termo justificaria a inclusão de instituições sem acervo, como centros culturais, espaços interativos, etc., mas seria como perguntar: existe mula sem cabeça? Existe e pode até mesmo vistosamente soltar fogo pelas ventas. No entanto, se o papel de mula tiver ainda utilidade, é duvidoso que, sem cabeça, a mula possa executó-lo a contento. E se o papel de mula for importante para a sociedade, com a mula sem cabeça alguma coisa ficaria faltando. A pergunta correta, pois, deveria ser: há, ainda, relevância e utilidade, entre nós, no papel que possam desempenhar museus com acervo? A resposta é francamente positiva. Estamos imersos num oceano de coisas materiais, indispensáveis para a nossa sobrevivência biológica, psíquica e social. A chamada "cultura material" participa decisivamente na produção e reprodução social. No entanto, disso temos consciência superficial e descontínua. Os artefatos, por exemplo, são não apenas produtos, mas vetores de relações sociais. Que percepção temos desses mecanismos? Não se trata, apenas, portanto, de identificar quadros materiais de vida, listando de objetos móveis, passando por estruturas, espaços e configurações naturais, até obras de arte'. Trata-se, isto sim, de entender o fenômeno complexo da apropriação social de segmentos da natureza física (Meneses, 1983).

Esta conceituação supera a oposição entre cultura material e cultura não-material ou, ampliando, fenômenos sociais materiais e não materiais /ver, no domínio dos museus, a penetração destas perspectivas: Pearce 1992, Pearce ed. 1989, 1994, Lubar \& Kingery eds. 1993, Fleming, Paine \& Rhodes eds. 1993, Schlereth 1992). Neste rumo é que se compreende a afirmação de Edwina Taborsky (1990: 74), de que o museu só se interessa pelos objetos materiais por causa do sentido. E, nisso, ele tem condições de análise e entendimento que nenhuma outra plataforma em nossa sociedade iguala.

Ora, o museu, precisamente, constitui recurso estratégico pelo qual essa consciência pode ser alargada e aprofundada. No museu nos defrontamos com objetos enquanto objetos, em suas múltiplas significações e funções - ao contrário, por exemplo, do que ocorre num supermercado. Objetos de nosso cotidiano (mas fora desse contexto e, portanto, capazes de atrair a observação) ou estranhos à vida corrente (capazes, por isso, de incorporar à minha as experiências alheias). Doutra parte, é a função documental do museu (por via de um acervo, completado por bancos de dados) que garante não só a democratização da experiência e do conhecimento humanos e da fruição diferencial de bens, como, ainda, a possibilidade de fazer com que a mudança atributo capital de toda realidade humana - deixe de ser um salto do escuro para - vazio e passe a ser inteligível. Enfim, seria bom lembrar que, ao se falar em acervo, é preciso acrescentar ao acervo cartorialmente definido, de posse institucional do museu, aquele acervo operacional (porque é sobre ele que o museu opera), constitúdo por todo aquele tipo de evidência - que pode estenderse a um território inteiro (Suano 1978: 122-3, Meneses 1984-5: 200-1). Todavia, ainda persistem posições conservadoras, que assumem
radicalmente a desimportância das coleções, as quais chegam, até mesmo, a 
ser apresentadas como estorvo. Um porta-voz desse extremismo é Julian Spalding, diretor dos museus e galerias de Glasgow, segundo o qual os museus não mais poderiam continuar a funcionar meramente como storage facilities - 0 que, sem dúvida, me parece observação pertinente e sensata. A alternativa, entretanto, é desconcertante e já vem expressa no título de seu artigo: "Interpretation? No, communication" (Spalding 1993). Comunicar seria, em última instância, atender aos interesses do público: até agora, os museus têm tentado "to tell the public what interests us - instead of asking what interests them" (ib.: 11). Sem meias palavras, Spalding conceitua: "Museums are in the interest business. Our job is to generate interest" (ib.: 13). Por isso, reformulou as carreiras profissionais nos museus de sua cidade, onde não há mais curadores encarregados das coleções /coleta sistemática, documentação, estudo, etc.); agora há apenas um Conservation Department, cujo objetivo precípuo é tornar as coleções acessíveis, com segurança, acoplado a um Creative Services Department, incumbido de "generate interest" (ib.: 14). Tudo isso tem motivação das mais nobres: "I wish to put the people we serve at the absolute centre of our museum"lib.: 11). Apesar da meritória intenção, o resultado só pode ser socialmente prejudicial. A especificidade do museu (com tudo aquilo que ele poderia fazer enquanto museul dissolve-se nessa atmosfera rarefeita e, apesar das aparências, socialmente descompromissada, engolfandose numa visão tão ingênua de indústria cultural que ignora até mesmo que interesses (seja lá o que esta expressão designar) jamais são naturais, jamais socialmente inocentes. Doutra parte, caixeiros diligentes, os ex-curadores têm agora que investir apenas em sua habilidade na transferência daquilo que atende aos reclamos do consumidor, evitando qualquer risco de contaminar os produtos adequadamente embalados para consumo. De guardiães de tesouros e preceptores autoritários, que eram, passaram a eunucos culturais, responsáveis pelo acesso, aos destinatários legítimos, nas condições desejáveis, de bens dos quais não precisam mais ter experiência. Esta gratificante candura na concepção espontaneista da vida social não apenas é inepta, mas social e politicamente condenável, por constituir uma acabada receita de alienação, eliminando do horizonte qualquer perspectiva crítica. Com isso, joga-se fora a criança com a água do banho, reduzindo-se a coleção a um balcão de significantes prêt-à-porter já com todos os seus significados quintessencialmente embutidos, ou então, o que termina na mesma vala comum, almoxarifado de significantes disponíveis para os significados escolhidos self-service pelos usuários, sem qualquer mediação, supõe-se, de processos cognitivos e até mesmo das forças que agem no interior da sociedade capitalista em que vivemos.

Sem restringir o museu a um centro de documentação, seria socialmente leviano, porém, marginalizar suas responsabilidades documentais no campo da cultura material. A não ser que se projetasse outra forma institucional de preencher tais responsabilidades, caso em que poderíamos transferir-the a denominação tradicional de museu... Em suma, sem museu com acervo, a inteligibilidade do mundo material sofreria rude golpe em qualquer sociedade complexa. O desenvolvimento das técnicas de 
2. A bibliografia sobre o museu histórico é volumosa e de qualidade e interesse muito desiguais. Para não sobrecarregar ainda mais o presente texto, fica reservada para um número posterior dos Anais do Musen Pau lista uma bibliografia seletiva comentada ( $O$ número especial da revista Museum dedicada ao tema "Nouveaux aspects du musée d'Histoire", 1977 inclui bibliografia seletiva, p.180 ss.). reprodução, da telemática etc., não reduzirá, penso, a função do museu no domínio da documentação. Ele continuará a justificar sua existência pela necessidade de dar conta da apreensão sensorial, empírica, corporal, exigida pelo universo da cultura material (sem esquecer implicações sociais, como as da "aura" ou da fetichização - de que os museus são os instrumentos ideais, não de cultivo, é claro, mas de análisel. Além disso, no museu, a dimensão cognitiva sempre se imbrica, profundamente, na afetiva. Estou convicto de que, no século $X X \mid$, os museus não serão espaços anacrônicos e nostálgicos, receosos de se contaminarem com os vírus da sociedade de massas, mas antes, poderão constituir extraordinárias vias de conhecimento e exame dessa mesma sociedade. Serão, assim, bolsões para os ritmos personalizados de fruição e para a formação da consciência crítica, que não pode ser massificada.

Nessa perspectiva, a produção de "eventos" e o funcionamento do museu como "centro cultural" são legítimos e desejáveis apenas para multiplicar e potenciar as funções do museu enquanto museu: não para fugir delas, com substituições mais cômodas, como é muito freqüente, quando não se consegue dar conta do enfrentamento desse universo complexo da cultura material, seja no nivel propriamente da curadoria, seja no do conhecimento. Em outras palavras, aqui - como em vários outros pontos, tal qual se verá adiante - a palavra de ordem seria a integração do museu a outros patamares de ações e funções, além das que the são consubstanciais; jamais manter o museu como mero álibi para, em vez de museu, atuar segundo outras plataformas que, por si, exigiriam maior eficácia.

Tipologia de museus: o museu histórico

As presentes reflexões estão centradas no museu histórico. Rigorosamente, todos os museus são históricos, é claro. Dito de outra forma, o museu tanto pode operar as dimensões de espaço como de tempo. No entanto, do tempo jamais poderá escapar, ao menos na sua ação característica, a exposição. Harbison (1988: cap.8), partindo da própria configuração física do museu, examina o edifício na sua função de organizar o tempo no seu quadro. E Crang, desenvolvendo as perspectivas apontadas por Ricoeur, sobre as práticas narrativas como ordenadoras do mundo, concebe o museu "as machines that inscribe time on space" (Crang 1994: 32). Segundo o autor, eles encapsulam o tempo, usando suas categorias analíticas para segmentá-lo e representá-lo exibindo periodizações e estabelecendo hierarquias pela alocação diferencial e mobilização do espaço.

No entanto, condensou-se uma categoria específicia de museu histórico². Na Europa, como demonstra Bann (1990), há duas invenções expositivas que vão decisivamente nuclear a poética distintiva do moderno museu histórico, contribuindo para the definir a natureza. Elas se exprimem, de um lado, pelo Musée des Monuments Français, criado em 1795 e, de outro, quase vinte anos depois, pelo Musée de Cluny, ambos em Paris (ver também Poulot 1986). 
No primeiro se tem um princípio diacrônico, quando Alexandre Lenoir, artista, conhecedor e classificador de monumentos e esculturas medievais, organiza a galleria progressiva. (Museus de arte e arqueologia, galerias de retratos, etc. mais tarde, puderam servir de matrizes de museus históricos, matriz mais tarde ainda reforçada pelos museus militares).

Já no Hôtel de Cluny, Alexandre du Sommerard, quando montou a Chambre de François ler., lançava as bases do que posteriormente seria denominado period room, ao sincronicamente dispor, num mesmo espaço referido ao início do século $X V \mid$ e ao monarca francês, camas com dosséis, armários, mesas, tapetes e alfaias, armas e objetos de luxo e pessoais.

No século XIX, o desenvolvimento dos museus históricos está associado ao surgimento das nacionalidades (Horne 1984), ao mesmo tempo que, sem contradição, à História Universal, na qual a História Nacional representaria a culminação do desenvolvimento da civilização. Daí a importância dos museus de arqueologia das civilizações clássicas da Grécia e de Roma, bem como do Egito e da Mesopotâmia (Bennett 1994).

Nas Américas, as raízes são um pouco diversas. Definem-se, nos Estados Unidos, entre 1740 e 1870, quando se consolida o American compromise de que se ocupa Joel Orosz (1990), gerado no influxo do lluminismo europeu, mas temperado com os ideais republicanos da jovem nação, a emergência das classes médias e o advento do profissionalismo na ciência (e no museu). Educação popular e pesquisa acadêmica são os eixos que o compromisso americano desenvolve a partir de museus complexos, basicamente modelados como museus de História Nałural, aos quais também se integra a atuação de sociedades históricas e arquivos. Disto resulta um certo alargamento de horizonte e uma organicidade que, por exemplo, nos museus do pioneiro Charles Wilson Peale já incluía a tecnologia como traço distintivo da nação independente cuja identidade se procura firmar Helm 1992; ver ainda Wallace 1986, Swank 1990).

No Brasil, o modelo oitocentista é, também, o do museu de História Natural, no qual se insere organicamente a Antropologia e, como um enclave evocativo e celebrativo, a História. Somente na década de 20 deste século é que se condensa o museu histórico como categoria distinta das demais ${ }^{3}$.

A fragmentação dos museus em especialidades tem também sua hisłória que aponta para o século XVIII e que está ainda por ser feita. $O$ resultado é uma tipologia multiforme, em que, ao lado de museus enciclopédicos /do tipo do British Museum ou do Metropolitan Museum) e dos históricos, se encontram museus de arte, de arqueologia, de antropologia, de folclore, de História Natural (desmembrados em zoologia, botânica, geologia, etc.), de ciência e tecnologia e assim por diante. Finalmente, há os temáticos e micro-temáticos, muitas vezes corporativos e patrocinados por empresas: dos transportes, do mar, do telefone, das abelhas, da madeira, de moedas, selos, medalhas, do chapéu, da Coca-Cola e da farmácia. A pulverização não tem limite.

Esta fragmentação toda milita contra o reconhecimento de uma sociedade complexa (Horne 1992: 66) e tem repousado na referência que se tornou exclusiva: o objeto e sua nałureza, que, em última instância, determinaria
3. Já começaram a surgir alguns estudos sobre nossos museus históricos e seus antecedentes, substituindo trabalhos mais antigos, de perspectiva descritiva (como Sodré 1950): Abreu $1991 \mathrm{e}$ neste volume (Museu Histórico Nacional), Santos 1989 e $1992(\mathrm{Mu}-$ seu Histórico Nacional e Museu Imperial), Heizer 1994 (Museu Imperial), Mourão 1994 (Museu da Inconfidência), Schwarcz 1993 (os quatro museus oitocentistas). Há dois sucintos apanhados descritivos, por Lacombe $1977 \mathrm{e}$ Barata 1986, como também alguns catálogos ilustrados (Paiva 1984, Godoy 1989). Outros trabalhos se preocuparam genericamente em denunciar os compromissos ideológicos dos museus históricos ( $\mathrm{Si}$ môes Neto 1988, Lara 1991, Funari 1994). Além disso, há vários projetos em curso (Cecília Helena Salles de Oliveira, Ana Cláudia Fonseca Brefe, Maria José Elias, José Neves Bettencourt, etc.). 
a natureza do museu. Assim, essa taxonomia dos museus baseia-se menos em campos do conhecimento ou problemas humanos, do que em categorias de objetos, isolados ou agrupados, sempre, portanto, tendendo à reificação. Por isso, o conceito vigente é o de que museu histórico seria aquele que opera "objetos históricos".

Como resultado, a ciência e a tecnologia não incorporam a História e esta parece desprovida de qualquer conteúdo científico e tecnológico, mesmo depois da Revolução Industria. Num museu de arte, uma tela, por exemplo, é documento plástico (mas sem considerar que a construção da visualidade integra a realidade histórical. Já no museu histórico, a mesma tela seria valorizada pelo tema, como documento iconográfico (mas ignorando a historicidade da matéria plástica (ver Meneses 1992b). Foram critérios como esse que determinaram em 1904 e em momentos posteriores, a transferência de telas do Museu Paulista (hoje da USP, um museu então histórico, antropológico e biológico), para a Pinacoteca do Estado (um museu de arte).

A relação entre museu histórico e museu de arte sempre foi ambígua, pois há um compromisso de origem e uma oposição latente, ao mesmo tempo. Assim, por exemplo, na Inglaterra vitoriana e, mais ainda, nos Estados Unidos, os fundadores de museus exploraram a estética, nos museus históricos e antropológicos, para industriar e formar disciplinarmente o povo em geral e as classes operárias em particular e, num segundo momento, para reafirmar - nos EUA - valores americanos como contraponto aos riscos da imigração e, em seguida, estímulo ao progresso (Ettema 1987, Kammen 1991: 310-374). Quanto aos museus antropológicos sempre foram acusados de se apropriarem ideologicamente das "outras culturas", estetizando-as (Clifford 1985, Ames 1993, Price 19891. E os museus de "artes decorativas" muitas vezes constituíram um modelo variante de museu histórico (Froissart 1994).

É necessário, já se vê, esclarecer o que seja objeto histórico e se indagar que relação ele mantém com o documento histórico. Antes, porém, conviria tecer algumas considerações finais sobre a taxonomia de museus que inclui a categoria de museu histórico.

Está claro que não se pode ser totalmente negativo com relação às compartimentações apontadas. Ainda que sua justificativa não seja epistemológica, como se apontou, não há dúvida de que a descontinuidade é condição para o conhecimento $e$, assim, tais subdivisões podem criar condições favoráveis para aprofundar a investigação de um campo de fenômenos. Por outro lado, do ponto de vista documental, a natureza empírica das fontes não pode ser desconsiderada. Além disso, é bom também não esquecer que foi essa compartimentação que, entre nós, muitas vezes, assegurou a preservação do que de outra forma teria desaparecido. Finalmente, não são secundários os aspectos práticos e institucionais que levam a tal estado de coisas.

Resta, porém, o fato de que conhecimento e fonte não são biunívocos. A natureza da fonte não pode ser a mesma que a do conhecimento, nem determinar a natureza do conhecimento (pode, sim, definir limites, alcance, prioridades, pontos de força, etc.). Por isso, tomar um referencial exclusivamente documental, recortando tipos de objetos é procedimento insuficiente. 
Coleção ou problemas? É, antes, de uma problemática que se deve partir. Mas, já que se trata de museu, de uma problemática que possa ser montada (ou melhor montada) com objetos materiais. Portanto, instaura-se uma dialética, sem exclusão, em que a problemática define um horizonte de documentação potencial desejável e em que, por sua vez, categorias documentais permitem delinear territórios de problemas a serem formulados e explorados.

Ora, se a amplitude das problemáticas possíveis, na atual organização de museus, é reduzida le não há razões para prever mudanças radicais a curto prazo e nem mesmo para considerá-las desejáveis), nada impede a articulação de museus diferentes em torno de interesses comuns. $E$, na exposição, particularmente nas de curta duração, a flexibilidade destas articulações é inegável.

Uma ilustração tornará mais clara esta necessidade de considerar uma relação dialética entre objetos e problemas.

Um museu de cidade, por exemplo, pode contar com uma coleção de relógios de rua. E pode ampliar tipologicamente tal coleção e também expôla tipologicamente, em paralelo a várias outras classes de objetos, cada uma em seu segmento taxonômico. Pouco conhecimento se terá da cidade, salvo numa escala pontual e limitada. Sequer ficariam claras as funções desse tipo de monumento urbano. No entanto, caso se parta de um problema lque a própria coleção de relógios pode sugerirl, como a do tempo enquanto forma de controle social no espaço urbano, já se pode montar uma estratégia e mobilizar outras coleções existentes ou definir uma política de coleta. Asim, a partir do relógio de rua como referência que projetava no espaço urbano as significações do tempo enquanto fator de organização e convergência, numa sociedade em processo rápido de fragmentação, buscar-se-iam relações com outras formas de controle social por meio dos objetos pertinentes. Como, por exemplo, a domesticação do tempo nafural, pelas exigências da produção, que nossa sociedade impõe. A produção requer continuidade, mas o tempo natural apresenta rupturas, como a alternância dia/noite. Daí ser adequado incorporar à exposição coleções de equipamentos de iluminação (doméstica, industrial, de rual, capazes de permitir o entendimento deste domínio sobre o tempo. Outra relação poderia ser com o domínio da duração das coisas, da vida útil dos objetos reduzidos a mercadoria, a fim de que elas circulem mais rapidamente (é, portanto, a mesma matriz). Assim, a exposição contaria também com uma coleção de objetos descartáveis, como embalagens, copos, por exemplo, ou outros objetos marcados pelo efêmero ou pela obsolescência programada. Poderia parecer uma exposição compósita, eclética. De fato, mas nisso mesmo ela remete às múltiplas malhas da interação social, sem a qual escaparia o sentido histórico dos diversos tipos de objetos exibidos.

Objeto histórico, documento histórico.

Escrevendo n'O Paiz, na década de 20, quando no Brasil se definem os dois principais modelos mais antigos de museu histórico, o Museu Paulista e o Museu Histórico Nacional, assim talava José Mariano Filho (1.922: 1621, ecoando ainda a oposição entre objeto histórico e objeto artístico. 
"Casos há, e não raros, em que o interesse artistico apparece, por assim dizer doublé do interesse histórico. Seria o caso de se citar a cama do patriarcha José Bonifacio, uma das maiores maravilhas da talha executada no Brasil em fins do século XVII. Mas não é justo argumentar com as excepções. O tamborete tosco de Antônio Conselheiro, o lapis azul do monarcha Pedro ll, especie de guilhotina que invalidava em um simples traço a vida dos homens publicos; o catre de Diogo Feijó, tudo isso nada representa sob o ponto de vista artístico. São peças de Museu Historico, simples subsidios anedoticos, ou documentos curiosos ao sabor do paladar publico".

Quase setenta anos depois, um historiador australiano, Kimberley Webber, previa que "o cultivo de um sentido sério do passado" de seu país teria que "rest upon a clear distinction between the rhetoric of the relic and the reality of the artefact" (apud Bennett 1995: 146).

Por mais diversos que sejam, pela época, pelo contexto em que se inserem e pela perspectiva de que falam, estes dois testemunhos servem de emblema para consubstanciar um dilema (falso) ainda hoje atuante e que opõe, no museu histórico, estas duas categorias básicas de objetos.

A primeira é a categoria sociológica do objeto histórico que, em muitos museus, constitui presença exclusiva ou de clara prevalência. Na nossa sociedade, ele se caracteriza, quaisquer que sejam seus atributos intrínsecos, por sentido prévio e imutável que o impregna, derivado, não desses atributos, mas de contaminação externa com alguma realidade transcendental - por exemplo, a "vinculação a fatos memoráveis da história do Brasil" lacrescentariamos "e seus agentes excepcionais"), na expressão do Decreto-lei 35, de 1937, que criou o SPHAN - Serviço do Patrimônio Histórico e Artístico Nacional. São objetos singulares e auráticos, na expressão benjaminiana ou, mais precisamente, nãofungiveis. Não poderiam ser substituídos por cópias ou por objetos de atributos equivalentes. São excluídos de circulação e não só têm seu valor de uso drenado, como trazem para qualquer uso prático eventual a pecha do sacrilégio.

Malinowski percebeu com acuidade a semelhança existente entre os objetos do circuito do kula e as jóias da coroa britânica, que ele contemplou no castelo de Edimburgo. O kula é um ritual de troca de objetos, entre os nativos das Ithas Trobriand, marcado por regras numerosas e precisas e, além disso, respeitadas, pela integração social que propiciavam. Tanto quanto as jóias da coroa, os objetos do kula não valem pelo uso prático, "pois são possuídos pela posse em si". Posse que transfere glória e fama. "Podem ser feios e inúteis e, segundo os padrões correntes posssuir muito pouco valor intrínseco", arremata o famoso antropólogo, como se reproduzisse o mote de José Mariano Filho, "porém só o fato de terem figurado em acontecimentos históricos e passado pelas mãos de personagens antigos constitui um veículo infalivel de importante associação sentimental e passam a ser considerados grandes preciosidades" (Malinowski 1976: 80). São semióforos, expressão rebarbativa forjada por Pomian (1977) para identificar objetos excepcionalmente apropriados e exclusivamente capazes de portar sentido, estabelecendo uma mediação de ordem existencial le não cognitiva) entre o visível e o invisível, outros espaços e tempos, outras faixas de realidade. Escusado insistir que o conceito de relíquia, no campo religioso, condiz com os anteriores, ressaltando a necessidade de contigüidade, contacto com um 
transcendente, para que o objeto prolongue esse transcendente, seja, entre nós, 0 que dele ficou (relicta). Todos funcionam como fetiches, significantes cujo significado thes é imanente, dispensando demonstração: as relíquias do Santo Lenho, por exemplo, impunham credibilidade, não pela autenticidade de suas origens, mas pelo poder manifestado (Lowenthal 1992: 91).

Relíquia, semióforo, objetos históricos: seus compromissos são essencialmente com o presente, pois é no presente que eles são produzidos ou reproduzidos como categoria de objeto e é às necessidades do presente que eles respondem. Ou, em outras palavras:

"O objelo antigo, obviamente, foi fabricado e manipulado em tempo anterior ao nosso, atendendo às contingências sociais, econômicas, tecnológicas, culturais, etc.etc. desse tempo. Nessa medida, deveria ter vários usos e funções, utilitários ou simbólicos. No entanto, imerso na nossa contemporaneidade, decorando ambientes, integrando coleções ou institucionalizado no museu, o objeto antigo tem todos os seus significados, usos e funções anteriores drenados e se recicla, aqui e agora, essencialmente, como objeto-portador-de-sentido. Assim, por exemplo, todo eventual valor de uso subsistente converte-se em valor cognitivo o que, por sua vez, pode alimentar outros valores que o passado acentua ou legitima. Longe, pois, de representar a sobrevivência, ainda que fragmentada, de uma certa ordem tradicional, é do presente, indica Jean Baudrillard, que ele tira sua existência. E é do presente que deriva sua ambigüidade" (Meneses 1992a: 12).

Estas conotações temporais são, de fato múltiplas, embora o presente constitua o foco ordenador. Assim, o mesmo Baudrillard, apesar de opor o objeto antigo ao objeto funcional e localizá-lo na modernidade, não o considera a-tuncional. Sua função é precisamente significar o tempo:

"L'exigence à laquelle répondent les objets anciens est celle d'un être définitif, un être accompli. Le temps de l'objet mythologique, c'est le parfait: c'est ce qui a lieu dans le présent comme ayant eu lieu jadis, et qui, par cela même est fondé sur soi, 'authentique'" (Baudrillard 1968: 91-2).

Ao inverso, os objetos funcionais se esgotam no presente, comprometendo qualquer índice de plenitude e sem passado. Existem apenas no indicativo e no imperativo prático, como propõe Baudrillard.

Eis porque o decurso do tempo constitui fator relevante de qualificação do objeto histórico - a ponto de ser utilizado, automaticamente, como critério discriminatório. Alois Riegl, em obra clássica 11984, original de 1903) aponta como as marcas da passagem do tempo, a degradação física, as lacunas - fundamentam o critério maior de valor do objeto antigo, imediatamente perceptível lao invés do valor histórico, que remete a um conhecimentol. A posse de objetos históricos como vetor de classificação social não é tema novo, seja no tocante a coleções (Stillinger 1980), seja em mecanismos mais individuados, como a 'síndrome da pátina', que McCracken (1883) estuda na Inglaterra, nos processos de gentrification. 
Esta categoria de objeło histórico, assim, por sua própria natureza e funções, privilegia as classes dominantes - fato facilmente observável nos museus e abundantemente denunciado na bibliografia. Curioso é que este viés tenha como vetores seja o excepcional, principalmente na versão das artes decorativas (a belíssima cama de José Bonifáciol, seja o banal irrelevante (o lápis de D.Pedro II) que, por sua própria insignificância, serve de caução ao excepcional e à credibilidade dos valores que se devem exaltar. Nos dois casos, os vínculos pessoais são condição relevante e singularizadora. Com outros acréscimos, que constifuem variantes ou desdobramentos destas duas vertentes, tem-se um quadro verdadeiramente paradoxal: a visita à maioria dos museus históricos justificaria levantar-se a hipótese de que, aí, a matéria-prima com que se faz a História são móveis de classe, objetos de luxo (louça brasonada, p.ex.), pertences pessoais larmas, indumentária, moedas, quinquilharial, sem esquecer, é claro, símbolos do poder e, ainda, telas (pela força da imagem nas funções evocativas e celebrativas).

Torna-se evidente, destas considerações, que o objeto histórico é de ordem ideológica e não cognitiva. Não que não possa ser utilizado para a produção de conhecimento. Ao contrário, são fontes excepcionais para se entender a sociedade que os produziu ou reproduziu enquanto objetos históricos.

E quanto ao objeto purificado da retórica, o objeto concreto, idêntico a si próprio, aquela real thing que Webber almejava como antídoto à relíquia? Por certo não existe. Ou, na formulação de Bennett (1995: 146): "... the artefact, once placed in a museum, itself becomes inherently and irretrievably a rhetorical object".

Com efeito, o artefato neutro, asséptico é ilusão, pelas múltiplas malhas de mediações internas e externas que o envolvem, no museu, desde os processos, sistemas e motivos de seleção (na coleta, nas diversificadas utilizações), passando pelas classificações, arranjos, combinações e disposições que tecem a exposição, até o caldo de cultura, as expectativas e valores dos visitantes e os referenciais dos meios de comunicação de massa, a doxa e os critérios epistemológicos na moda, sem esquecer aqueles das instituições que atuam na área, etc.etc.

Poder-se-ia concluir dizendo que o objeto puro ou purificado, "the real thing" pode, sim, existir, mas somente saturado de hiper-realidade: "imagination demands the real thing and, to attain it, must fabricate the absolute fake" (Lowenthal 1992: 97; para a hiper-realidade e o simulacro, ver Eco 1984 e, já seduzido pelo virtual, Baudrillard 19811.

Suplantado o falso dilema relíquia (objeto histórico) versus artefato em si, resta saber que alternativa cabe ao museu histórico.

Segundo a tipologia museológica acima discutida, concebe-se correntemente o museu histórico como aquele que opera com objetos históricos. Se, contudo, é a dimensão do conhecimento que sobe à tona, é preciso retificar e dizer, como vimos, que o museu histórico deve operar com problemas históricos, isto é, problemas que dizem respeito à dinâmica na vida das sociedades. 
Nessa ótica, o museu deveria servir-se também dos objetos históricos, e de qualquer objeto que the possa permitir formular e encaminhar os problemas que tiver selecionado como prioritários dentro de seu campo. (É clara, além disso, a necessidade de emprego de fontes não materiais, que é preciso integrar às fontes materiais, às quais cabe a hierarquia, já que os problemas privilegiados, como também se viu, devem ser pertinentes, num museu, à dimensão física, sensivel, da produção/reprodução social). Introduz-se aqui a questão do documento histórico.

Para reduzir um complicado problema à sua mínima expressão, no nível empírico pode-se dizer que documento é um suporte de informação.

Há, em certas sociedades, como as complexas, uma categoria específica de objetos que são documentos de nascença, são projetados para registrar informação. No entanto, qualquer objeto pode funcionar como documento e mesmo o documento de nascença pode fornecer informações jamais previstas em sua programação. Se, ao invés de usar uma caneta para escrever, the são colocadas questões sobre o que seus atributos informam relativamente à sua matéria prima e respectivo processamento, à tecnologia e condições sociais de fabricação, forma, função, significação, etc. - este objeto utilitário está sendo empregado como documento. (Observe-se, pois, que o documento sempre se define em relação a um terceiro, externo a seu contexto originall. O que faz de um objeto documento não é, pois, uma carga latente, definida, de informação que ele encerre, pronta para ser extraída, como o sumo de um limão. $O$ documento não tem em si sua própria identidade, provisoriamente indisponível, até que o ósculo metodológico do historiador resgate a Bela Adormecida de seu sono programático. É, pois, a questão de conhecimento que cria o sistema documental. O historiador não faz o documento falar: é o historiador quem fala e a explicitação de seus critérios e procedimentos é fundamental para definir o alcance de sua fala.. Toda operação com documentos, portanto, é de natureza retórica. Não há por que o museu deva escapar destas trilhas, que caracterizam qualquer pesquisa histórica.

É importante notar que esta preocupação em conceituar o documento se encontra muito mais freqüentemente nos museus antropológicos do que em seus paralelos históricos. Paradoxal é que possam até mesmo ocorrer casos de pacífica convivência entre documentos e objetos históricos, na mesma instituição. Exemplo sintomático é o do Museu Paulista, criado em 1893 como Museu de História Natural, reproduzindo o modelo europeu, que introduziu a relação simbiótica mais perfeita entre museus e um determinado campo do saber. Mas a História, ao nele se inserir, cada vez mais se afasta dos princípios e normas de um museu de História Natural:

"Aliás, sua cômoda inserção em museus dessa categoria nunca implicou adesão a suas premissas, Pelas funções comemorativas que a própria legislação que - instituiu prescrevia, ficava patente que a História não tinha estatuto epistemológico, mas ético. Daí a convivência pacífica com o museu de História Natural, apesar da existência do que hoje nos pareceriam graves contradiçōes. Assim, a noção de coleção é estranha ao museu histórico, pois o acervo é composto de objetos 
singulares. A coleta de campo é absolutamente irrelevante; a permuta, desconhecida; a compra é prejudicada pelos altos custos do antiquariato; resta á doação, que introduz, com freqüência, os objetos como suporte da auto-imagem dos doadores. $O$ uso documental das peças é praticamente nulo. Predomina a metáfora, capaz de ilustrar, na exposição, conhecimento produzido alhures. A importância da iconografia se funda numa concepção visual da História, magistra vitae, e no poder de evocação e celebração da imagem. Por isso, o museu não apenas coleta documentos iconográficos, como passa a produzilos, encomendando-os a pintores e escultores, segundo prescrições bem definidas (Carvalho \& Lima 1993). Finalmente, é o prédio inteiro, arquitetura e um oceano de figuras que, do saguão ao salão nobre, passando pela escadaria monumental, com seus quadros, nichos, molduras e brasões estucados, plataformas e bases para esculturas etc., se organiza alegoricamente para evocar e celebrar a transformação do território em nação independente. Taunay, nos anos 20, introduz nesse imaginário da Independência a ideologia paulista lo projeto hegemônico de São Paulo na República Velha estava, então, sendo contestado). O bandeirante, associado à proeza da extensõo do território e predecessor do tropeiro, do fazendeiro de café e do capitão de indústria, tem suas iconografia e ideologia gestadas no Museu Paulista. A presença do bandeirante serve para avaliar a autonomia da História com relação às demais áreas de conhecimento no museu: este predador de índios convive pacificamente com sua presa, abrigada na seção etnográfica... Aliás, o índio da História lpor exemplo, de uma tela como O desembarque de Cabral em Porto Seguro, 1500, de Oscar Pereira da Silval e o índio documentado pela Arqueologia e pela Etnografia sempre mantiveram identidades separadas, sem jamais se terem cruzado sob o mesmo teto institucional. Este descompromisso da História como forma de conhecimento é o que explica o fato de o acervo museológico do Museu Paulista nunca fer sido utilizado como fonte para a pesquisa histórica. Não era esta a sua função. Era, sim, a do Arquivo Histórico, criado pelo mesmo Taunay - autor, diga-se de passagem, de uma obra copiosa, toda ela basicamente fundamentada em fontes escritas" (Meneses 1994: 576-7).

\section{A exposição histórica}

Antes de entrar na especificidade da exposição histórica, impõe-se examinar uma série de questões gerais, ainda que ressaltando o que possam ter de mais relevante para as exposições históricas: a exposição como convenção, o falso binômio objetos versus idéias e a exposição como linguagem.

\section{A exposição como convenção}

A característica basilar e de cujas implicações pouco nos damos conta é o caráter da exposição como convenção visual, organização de objetos para produção de sentido. A exibição de peças museológicas como vetor de sentido não se confunde com outras operações semelhantes (por exemplo, a ostensão ritual de objetos, que não depende de seu valor "documental", referência externa, mas de seu valor imanentel. É impossivel tratar a exposição, assim, como um processo natural, óbvio, espontaneamente operável (Pearce 1992: 137). A "linguagem do museu" não pode, pois, ser tomada como linguagem natural e é vã procura de recursos que permitam uma "comunicação imediata".

Levando em conta a dissolução, em nossa sociedade de classes, das 
poderia justificer o curso, tão reiterado entre nós, do termo comunidade no universo dos museus), é forçoso reconhecer que o uso do museu não se inclui nos processos formais e informais de enculturação vigentes entre nós - como, por exemplo, a alfabetização ou o domínio dos códigos visuais da publicidade, da comunicação de massas etc. A diferenciação etária, sexual, educacional, profissional, de gosto, etc., além, é claro, da econômica e, numa palavra, social, com a geração de diferentes sistemas de valores e códigos diversos de comunicação, implicam uma enorme fragmentação da linguagem que só a indústria cultural se apresenta em condições de enfrentar (por ter investido na eficácia e com métodos e objetivos, é natural, que não coincidem com aqueles próprios dos museus e das exposições).

Nessa ótica, a primeira orientação de uma exposição deveria ter como meta a 'alfabetização museológica'4. Ellie Caston, que coordenou os programas interdisciplinares do Carnegie Museum of Natural History and Art, realisticamente apontava que a função educacional do museu não seria completa se ele não ensinasse o que é um museu, o que é uma exposição e como devem e podem ser usados: "museums in addition to everything else they may do, must be concerned with educating people about museums as museums... (with) developing audiences for museums - as multifaceted resources for use" (apud Schlereth 1992: 315).

Isto, evidentemente, não equivale a presumir que uma exposição só será devidamente fruida com a mediação, suponhamos, de um monitor. Seria o mesmo que pressupor a presença de um alfabetizador a cada leitura de um texto. Ao contrário, deve-se fixar como alvo a capacitação do usuário para dominar a convenção. É preciso, pois, acentuar a importância das questões metodológicas entre as obrigações básicas que os museus precisam assumir.

Outra questão gravíssima que a natureza convencional da exposição acarreta numa sociedade compartimentada é a impossibilidade de se dispor de uma moeda comum, polivalente, universal, ao alcance de todos os grupos e segmentos. De um ponto de vista meramente formal, poder-se-ia fazer paralelo, mais uma vez, com a aprendizagem da leitura (aquisição da competência para fazer uso personalizado de exposições), que não equivale ao entendimento de todo tipo de texto la exposição específica, enquanto expressão de um determinado conceitol. No entanto, na prática, vejo com dificuldade solução para o impasse. Na impossibilidade de se contar com um miraculoso Esperanto museológico, conviria apenas adiantar, como imagino, que se deva desenvolver a exposição a partir de um núcleo básico e simples, em que predomine a linguagem dos objetos (ver adiante) e em torno do qual se expandam camadas concêntricas /conforme as faixas de diversificação possiveis de atingir) - mas sempre voltadas para o mesmo núcleo básico em questão e de crescente complexidade.

Contudo, a tendência dominante, acentuadamente, é a de definir um público-alvo (target audience). Infelizmente, tal tendência tem-se embasado, cada vez mais, não na consideração das responsabilidades do museu com relação à
4. O problema da "alfabetização museológica" tem sido levantado com certa freqüência (cf. Rice 1988; Stapp 1984), mas de forma ainda ligeira $e$ associada, em geral, às artes visuais. Às vezes se aproxima, mesmo, das propostas da arte-educação. No entanto, o horizonte aqui proposto é mais amplo e deveria abranger todo o campo da cultura material e, dentro dela, alguns segmentos institucionalizados, como é o caso dos museus. 
diversificação de usuários, mas nas exigências do mercado. Nos Estados Unidos, a tendência já se tornou padrão, nos grandes museus. Com efeito, exposições cujos orçamentos beiram milhões de dólares (como a dos 'tesouros' de Tutancâmonl e que contam com pesados investimentos privados, não podem ter fracasso de público. É forçoso, então, que se busque o retorno a qualquer custo com o que os museus mergulham indiscriminadamente na comunicação de massas e na indústria cultural (e de entretenimento), sem preservar qualquer especificidade, nem mesmo a de eventualmente servirem como filtro crítico, num mundo no qual as massas são uma realidade inelutável (para o bem e para o mall e impossivel de ignorar.

A principal decorrência desse estado de coisas é o enfraquecimento da dimensão política do museu, muitas vezes substituída pelo paternalismo, ou, mais raramente hoje, pelo elitismo. Ora, o museu que não se preocupa com preparar seu público para operar uma convenção enquanto convenção /e avaliá-la em suas conseqüências), mas simplesmente busca sua adesão ou induz, às vezes com sedutora conivência, à aceitação e reforço de um sentido já cristalizado, este museu estará sempre vulnerável às pressões da despolitização, seja elitista, seja populista.

Objeitos ou idéias?

Este novo dilema - objetos ou idéias (sentido, conceitos, problemas)? - tem sido colocado, como já se aludiu acima, referido ao museu como um todo (cf. Schlereth 1980) e é uma variante do dilema - templo ou forum? Entretanto, é na exposição que ele assume contornos bem explícitos.

O que é exposição: uma exibição que oferece ao olhar objetos, ou idéias? A exposição museológica somente poderia exibir objetos circunscritos em sua própria concretude como um ritual de idolatria. Tudo o que se debateu até aqui, porém, em especial o caráter convencional da exposição, conduz a direção diversa, em que o objeto aparece fundamentalmente como suporte de significações que a própria exposição propõe.

Até mesmo o desfrute estético jamais existe em estado puro. Esta fruição sensorial encontra na exposição de arte, como seria de esperar, seu espaço ideal. Ernst Gombrich, num artigo polemicamente intitulado "Deve o museu ser ativo?" (1987: 189-194), advogava a superioridade da contemplação, reduzindo qualquer "preocupação morfológica" na apresentação das obras a não mais que "fresh method of display which will be written up by press and discussed at cocktail parties but will this nine-day wonder really bring the nine-hundred-years wonder of craftmanship (as obras) nearer the beholder?" (ib: 189). E termina dizendo que os curadores (conservators) dos museus deveriam ser fiéis ao significado etimológico do termo que os designa e dispor-se a "that rarest of abilities, the ability to leave well alone" (ib.: 194). As farpas do conhecido historiador da arte se dirigem, sem dúvida, às pretensões dos escritórios de design laos quais cada vez mais se tem atribuído a montagem de exposições) em obter o monumental e o espetacular, ou então, 
aquele tão almejado 'total environment of communication' (Miles \& Zavala 1994: 147$)^{5}$.

Todavia, é bom reiterar que tal postura extrema, ainda que fosse desejável, seria inviável. Não há como assegurar tal recolhimento contemplativo absoluto, salvo numa utopia como aquela que Friedrich Schlegel formulava há quase dois séculos, para evitar que, no museu, cada quadro perturbasse o vizinho: o oratório privado, imerso em obscuridade, com apenas uma imagem iluminada (Recht 1989: 85). A história dos museus de arte revela a rejeição de tal partido, de sorte que todo museu da espécie (incluindo os de arte contemporânea, aqueles mesmos que Argan opunha ao caráter 'patrimonialista' dos museus de 'arte antiga') é, em última análise, um museu de história da arte. Ainda que não haja um conceito explícito, um conceito implícito sempre estará presente como princípio organizativo. Recht (1989: 86), ao descrever um dos tipos da exposição de quadros nos períodos clássico e barroco leixo de simetria, telas suspensas segundo regras de equilíbrio quanto a tema e/ou dimensão e referidas a uma tela, no meio, tida como principall, infere que assim se tecia uma "histoire de l'art autour de chefs-d'oeuvre, de faits majeurs, que les oeuvres contigües sont destinées à mettre en valeur ou par rapport auxquelles elles doivent recevoir leur signification propre" (ver também McClellan 1984).

Da mesma forma, os conceitos subjacentes à aparente desordem e heterogeneidade dos gabinetes de curiosidades dos séculos XVI e XVII (como se pode ver nos estudos reunidos por Impey \& MacGregor, eds. 1985), permitem concluir a presença de um modelo miniaturizado e uma totalidade, cujo sentido tinha sido precisamente formulado.

Também quanto aos museus históricos e antropológicos, já se notou abundantemente que não pode haver, nunca, exibição neutra ou literal de artefatos. (As premissas e os compromissos são sempre muito densos). A exposição museológica pressupõe, forçosamente, uma concepção de sociedade, de cultura, de dinâmica cultural, de tempo, de espaço, de agentes sociais e assim por diante (Shanks \& Tilley 1987). Nessa medida, a taxonomia proposta, desde 1836 por Worsae e Thomsen (Pearce 1992: 103) para organizar $\circ$ 'sistema das três idades' arqueológicas nos museus (idades da pedra lascada, polida e dos metais) é simplesmente um esquema evolucionista que parte de referencial morfológico e funcional e de índices de complexidade tecnológica para justificar 'seqüências e estágios'. Escusado insistir na assimilação do papel que tal sistema teve na organização dos acervos e das exposições, até os dias de hoje. $O$ evolucionismo e o funcionalismo são perspectivas, aliás, que, declarada ou sìbrepticiamente, organizam a maior parte das exposições arqueológicas e antropológicas.

Nos museus de ciências naturais, por sua vez, a explicitação dos princípios e pressupostos na organização de coleções e exposições sempre foi norma nos séculos XVIII e XIX. Mais ainda, é no museu de História Natural oitocentista que se encontra, como se disse, a articulação mais intima e fecunda entre museus e produção de conhecimento. Na realidade, é o único modelo (com seu derivado antropológicol que funcionou plenamente como instrumento institucional da contribuição museológica à atividade científica. Conceitos e
5. O problema neste passo levantado, de uma fruição discretamente estética (e, consequientemente, da possibilidade de outras formas, também discretas, de fruição: histórica, antropológica, etc., ou então, modalidades, como a educacional e assim por diante), apesar de seu relevante interesse, não será desenvolvido aqui. Em primeiro lugar porque as questões envolvidas (como, em Douglas Crimp 1993, o historicismo museológico; ou en Phillip Fisher 1991, a ressocialização do objeto de arte no museu; ou em Otília Arantes 1993, a exposição como quermesse - eletrônica ou não -, conflitando com o necessário recothimento) têm sido formuladas essencialmente a partir da ótica da arte; só recentemente começou a estender-se para outros campos (cf. Vergo 1994). Em seguida, porque tais questões exigiriam uma discussão museografica; ora, a museografia ê aqui referida apenas nas suas implicações para elucidação de problemas conceituais. 
categorias como coleção (inclusive diferencialmente destinada à pesquisa e à exposiçãol, coleta de campo, conservação, classificação, espécime, tipo, duplicata, etc.etc., de que dependia o avanço da disciplina, também foram essenciais no campo do museu. A exposição, principalmente no século passado, sempre esteve ajustada aos estágios mais avançados das ciências da natureza. A hierarquia e as relações espaciais, nas galerias de exposição, davam conta das necessidades e dos objetivos classificatórios como forma de conhecimento (SheetsPyenson 1988; Pearce 1992: 91-1 15). É apenas em nosso século que se dá uma ruptura profunda e cada vez mais aberta, nos museus de 'História Natural', entre coleções/pesquisa e exposições - o que tem multiplicado, segundo alguns biólogos, como Van Praëł (1989), os riscos de mistificação. Esse autor aponta como um dos fatores de ampliação da ruptura a moda, cada vez mais corriqueira, do diorama, o desaparecimento de objetos originais em exposição, assim como rumos, nas ciências biológicas, menos dependentes de coleções (ib.: 29).

É interessante - e inquietante - observar que é justamente nos museus de História Natural que se travaram alguns dos mais acirrados embates corporativos registrados na Inglaterra (por exemplo, no Museum of Natural History, South Kensington) e nos Estados Unidos (por exemplo, no Field Museum, Chicagol, entre pesquisadores, educadores e designers, loteando em territórios quase incomunicáveis cada área de atuação - e deixando sem qualquer consideração a presença de museólogos que não fossem profissionais de ciência, educação ou design.

Enfim, no caso dos museus de ciência e tecnologia, as exposições ou se apresentam comparáveis às dos museus históricos, ou funcionam (particularmente nos centros de ciência) como espaços de demonstração - às vezes espetaculosa - de conceitos e problemas científicos (Parr 1992), e não para apresentação de documentos.

\section{O objeto na exposição}

A natureza da exposição como convenção, a distinção entre objeto histórico e documento histórico, a relevância do problema do sentido e dos quadros de referência - são questões para as quais as reflexões acima apontam direções. O que não quer dizer, porém, que a exploração e o tratamento por que passam os objetos na exposição estejam claros.

Consequentemente, valeria a pena deter-se em alguns padrões costumeiros no que interessa à exposição histórica. São padrões muito imbricados uns nos outros, aqui discriminados apenas para melhor compreensão.

O objeto fetiche

A tendência mais comum no museu histórico, previsível pela caracterização corrente que dele se fez, é a fetichização do objeto na exposição. Inserida numa dimensão de fenômenos históricos ou sociais, a fetichização tem que ser entendida como deslocamento de atributos do nível das relações entre os homens, apresentando-os como derivados dos objetos, autonomamente, portan- 
to "naturalmente". Ora, os objetos materiais só dispõem de propriedades imanentes de natureza físico-química: matéria-prima, peso, densidade, textura, sabor, opacidade, forma geométrica, etc.etc.etc. Todos os demais atributos são aplicados às coisas. Em outras palavras: sentidos e valores (cognitivos, afetivos, estéticos e pragmáticos / não são sentidos e valores das coisas, mas da sociedade que os produz, armazena, faz circular e consumir, recicla e descarta, mobilizando tal ou qual atributo físico (naturalmente, segundo padrões históricos, sujeitos a permanente transformação).

Exposições meramente taxonômicas (numismática, porcelanas, mobiliário, armaria etc.) incorrem sempre em fetichização, mistificando os objetos. Não que o conhecimento especializado possa dispensar, no nível empírico, estes procedimentos classificatórios. Além disso, não haveria por que excluir do museu os interesses legítimos dos amadores, colecionadores especializados, experts. Daí que alguns museus tenham procurado oferecer, entre a reserva técnica das coleções e a exposição pública, "galerias de estudo", em que dão acesso visual direto às peças dispostas conforme sua classe.

Naturalmente, sistemas classificatórios mais flexíveis, como os de natureza geográfica, cronológica, funcional, etc., quando exclusivos, também absorvem os efeitos desfiguradores da fetichização.

Uma forma sutil de fetichizar é a estelização do objeto: ela remete a uma "humanidade imanente", em geral para escapar ao "pesadelo da história" (Shanks \& Tilley, 1987: 73).

Se é limitador, para a exposição, fetichizar objetos, é, ao contrário, de extremo interesse procurar registrar e explicar a fetichização, estudar e dar a conhecer o objeto-fetiche. Em conseqüência, ao invés de eliminar os "objetos históricos", as relíquias, o museu histórico deve é inseri-los no seu quadro de análise e operações, procurando desvendar sua construção, transformações, usos e funçōes. Deportar as relíquias seria incidir no crime perpetrado por Rui Barbosa, ao propor, após a Lei Áurea, a destruição dos documentos relativos à escravidão, por ser esta moralmente inaceitável.

Mas, como desfetichizar o objeto, na exposição? Simplesmente trilhando o caminho inverso da fetichização, isto é, partindo do objeto para a sociedade. Ao invés de fazer história das armas, por exemplo, dar a ver a história nas armas: expor as relações do corpo com a arma, como mediações para definir o lugar do indivíduo (armas brancas), do grupo (armas de fogo, padronização, disciplina), da multidão urbana, perigo latente (pistolas miniaturizadas) e assim por diante (Carvalho 1992). Ou tomando o mobiliário colonial de São Paulo como índice para assinalar e compreender as condições e padrões de assentamento, na mobilidade e graus de acesso de arcas, canastras, cômodas (Suano 1992). Ou ainda, utilizando liteiras e cadeirinhas para questionar o espaço público como cenário de classificações sociais e os deslocamentos pessoais em relação às escalas do olhar (ver, ser visto, dar a ver) (Barbuy 1992). Ou, enfim, expondo a tela de Benedicto Calixto, A fundação de São Vicente, de 1900, não como "representação" da origem da futura cidade, em 1532, mas como vé́culo do imaginário da virada do século XIX, relevante para o conhecimento de conceitos oitocentistas e representações 
sociais que se reportam a cidade, território, instituições, colonização, relações inter-étnicas etc. (Meneses 1992b).

O objeto metonímico

Tomar a parte pelo todo é procedimento que caracteriza mais propriamente as exposições antropológicas, mas da qual não está imune a exposição histórica.

Com a metonímia, o objeto perde seu valor documental, transmuta-se num ícone cultural, de valor, agora, puramente emblemático. É o que ocorre quando objetos (no caso da História, também os eventos reificados) são mobilizados para afirmação ou reforço de identidades. Ora, a identidade é um processo, não um produto, que só pode ser apreendido e entendido em situação, não abstratamente la identidade se define sempre por oposição a uma alteridade e conforme escala móvel que o jogo dialético produz). Transformá-la numa quintessência, que pode ser perdida, resgatada etc. é pura ilusão. O emprego do "típico" (fácil de descambar para o estereótipo), constitui simplificação que inelutavelmente mascara a complexidade, o conflito, as mudanças e funciona como mecanismo de diferenciação e exclusão (Meneses 1993).

Por outro ângulo, imaginar-se que é possível, por intermédio de exposições museológicas, expressar a "significação" de determinado grupo ou culura, "povo", nação ou segmento social é ingenuidade em que os museólogos profissionais não poderiam cair. Não é possível, decididamente, exibir culturas (e as categorias correlatas que se acabou de apontar). Muitos dos trabathos incluídos na coletânea de Karp \& lavine (eds. 1991), com esse título, tornam patentes os desvios ideológicos da metonimização. Aliás, foi com esse suporte museológico que a Antropologia Cultural do fim do século passado e inícios deste forneceu suporte à expansão colonialista européia.

O objeto metafórico

Juntamente com o emprego do objeto-fetiche, é o caso mais corrente na exposição histórica.

O uso metafórico do objeto, numa mera relação substitutiva de sentido, talvez não seja tão nocivo quanto os que já foram expostos. Mas torna inócuo o museu, por reduzir a exposição a uma exibição de objetos que apenas ilustram sentidos, conceitos, idéias, problemas que não foram deles extraídos, mas de outras fontes externas, independentes daquilo que se está apresentando. Ao falar do propósito de "assembling a museum collection that illustrates historical events", D.R. Richeson (1985: 56), exemplifica atitude dominante, que elimina a vantagem peculiar do museu e de sua característica mais poderosa: o trabalho com o objeto. Esta postura revela, assim, uma incapacidade de se defrontar com o objeto, de explorá-lo em seus próprios termos. Em lugar disso, preferem-se suportes aos quais já se está habituado, como os suportes verbais, não só para formular os conceitos, mas também para comunicá-los: nesta linha, de fato esvazia-se a utilidade de um museu com acervo. 
Esta tendência, reveladora de despreparo, inércia ou desorientação, não é nova. Há um século, George Brown Goode, que foi um dos grandes diretores do Museu de História Natural da Smithsonian Institution, em Washington, dizia ironicamente que uma boa exposição didática era aquela que dispunha de uma coleção instrutiva de legendas, cada uma ilustrada por um espécime bem escolhido lapud Belcher 1991: 62).

Com esta transferência de responsabilidade para legendas, painéis, audiovisuais, recursos de multimídia e dispositivos interativos, não deve causar estranheza um padrão de visita escolar que ocorre com freqüência no museu histórico, quado os visitantes são solicitados, por seus professores, a copiar todas as informações escritas disponíveis, esquecendo-se de chamar a atenção para aquilo que seria específico do museu: o objeto. Não há dúvida de que uma exposição que dispensasse eses apoios multi-sensoriais correria o risco de fetichizar os objetos. $O$ problema começa quando o que seria apoio se transforma em espinha dorsal. Da mesma forma, seria absurdo recusar a cesariana: mas talvez valesse a pena aplicá-la somente quando se esgotassem as possibilidades do parto outrora dito natural.

A instalação artística

Ainda que sumariamente, impõe-se dizer algo quanto à nova moda que começa a tomar corpo entre nós e que deriva, também, de um tratamento metafórico dos objetos museológicos. É a crença de que a instalação artística seria a nova tábua de salvação, capaz de destravar e unificar as línguas balbuciantes dessa babel que é a exposição histórica.

A instalação surge, na arte contemporânea, dentro das preocupações da arte conceitual para superar o estatuto da obra encerrada nos estreitos limites de sua materialidade, dependente de suporte físico. Desmaterializada ou estendida, a obra (ação, conceito) incorpora o espaço circundante, multiplica objetos e intervenções no ambiente.

Pierre Bourdieu, comentando a atuação de grandes artistas que se têm valido de instalações, como Hans Haacke, implacável crítico da "cultura mediática" e das hipocrisias do mecenato artístico, fala da importância de inventar formas de ação simbólica a serviço das lutas contra a violência simbólica. Obras nesse espírito são "máquinas simbólicas que funcionam como armadilhas e fazem entrar em ação o próprio público. (...) Estas obras fazem falar e diferentemente das obras de certos artistas conceituais, por exemplo, elas não fazem falar apenas do artista; elas fazem falar também daquilo sobre o que fala o artista" (Bourdieu \& Haacke 1995: 30).

Quando Haacke transforma o espaço central do pavilhão alemão na Bienal de Veneza, em 1993, com sua instalação Germania Ipela qual recebeu o Leão de Ourol, ele cria, com tapumes de madeira e placas estilhaçadas, inscrições monumentais de fachada, fac-símiles da moeda alemã e fotografias históricas, um contraponto crítico à visita de Hitler à Bienal em 1934, com extraordinário impacto emocional e capaz de dar a apreender profundamente uma certa historicidade (ib.: 111-135) 
Mas, conviria a instalação à exposição histórica? A instalação como parte de uma exposição, sem dúvida alguma. A instalação como forma ideal ou predominante, ou única, não, com certeza. A instalação é obra ambiental. Nessa medida, ela esvazia toda especificidade do documento histórico, que se amalgama com outros documentos e outros suportes, tudo metaforizado para produzir uma síntese estética.

Há, pois, espaço no museu histórico para instalações, assim como para performances e dramatizações (outras formas de metaforização que podem conduzir a deformações irreversíveis, como se verá mais adiante). Não é pouca a contribuição que elas podem trazer. A pretensão, porém, de as instalações substituirem as exposições analíticas mais uma vez revela a incapacidade de enfrentamento do objeto, da coisa material, preferindo-se a apropriação indolentemente ingênua de uma linguagem moldada em outro contexto e com outra economia. Nesse caso,z o museu histórico seria totalmente dispensável. Mas então, como dar conta da função seminal que lhe competia, em nossa sociedade?

Doutra parte, é preciso também acrescentar que instalações não podem ser improvisadas. Considerá-las como um código auto-operável, que dispensa consistência como obra plástica é cair de imediato no pastiche, dando à instalação um caráter puramente mítico - no sentido utilizado por Barthes (1957: $216)$, quando diz que o próprio do mito "c'est de transformer un sens en forme".

A contextualização museológica do objeto

A consideração rotineira de que o objeto descontextualizado se desfigura tem colocado, legitimamente, a questão do contexto e a necessidade de reintroduzito na exposição. Estranhamente, porém, não se tem visto qualquer esforço na conceituação do que seja contexto e de como, quando e por que ele permite ampliar as significações do objeto. Por isso, tem-se tomado como solução imediata, pronta e acabada, a mera reprodução do contexto enquanto aparência visual, isto é, recorte empírico que, como tal, precisaria ser explicado, pois não é auto-significante. Alexandre du Sommerard, quando montou o germe dos period rooms em Cluny (v. retro p. 15 ), estava apenas organizando, sem o saber, um "sistema de objetos", de significação cronológica e funcional. Não procurava restituir "historicamente" o quarto de Francisco l.

Estar-se-ia desaconselhando a reconstituição de ambientes? Absolutamente não. O que se tem que evitar é confundir tais recontituições com "contexto". Esta suposição de que o dado empírico (o registro documental) pode ser tomado como informação, ou, pior ainda, como conhecimento ou síntese cognitiva, é responsável por alguns dos piores entraves ao conhecimento histórico em exposições museológicas, além de abrir espaço à ideologia, como apontam Shanks \& Tilley (1987).

Uma anedota narrada por Alexandre Vialatte, em 1952 le reproduzida por Dagognet 1993: 143-81 exemplifica excelentemente a ilusão de que contexto é o mero agrupamento de objetos tais como se encontravam na "vida real". A história é a das irmãs Comte, do interior da França, para as quais estaria faltando um museu do "objeto qualquer", o museu do museu em si, o museu 
da idéia de museu. Não um anti-museu - o que exigiria a escolha de objetos anti-museológicos, pressupondo critérios. Assim, legaram para tal fim sua casa, objetos e todos os pertences, a tudo enclausurando em vitrinas, tudo absolutamente contextualizado, pois nada se alterara de lugar, fora acrescentado ou subtraído. Vialatte conclui: "le musée (est) une simple attittude d'esprit: c'est ce qu'avaient si bien compris les demoiselles Comte. Le musée n'est pas dans la vitrine, mais dans la tête du visiteur" (Dagognet 1993: 146). Elas haviam, de fato, feito uma descoberta importante: em nossa sociedade, o museu é essencialmente uma forma institucionalizada de transformar objetos em documentos. Bastaria para tanto a intenção (ou ação) designativa? Não. A imobilização do valor de uso la reclusão em vitrinas) é um passo significativo. Assim também, não bastaram a manifestação volitiva e a inserção física num museu, para que o mictório de Duchamp tivesse transfigurada sua natureza original. Esta inserção define um quadro dialógico de motivações, expectativas e as respectivas estratégias. Por isso, ela implica em deslocamentos e associações que escapam ao acaso e que só o museu pode oferecer poderosamente. Ora, na casa das irmãs Comte, quais os deslocamentos e associações capazes de iluminar o que fora espaço de uma experiência cotidiana? $O$ cenário, por certo, está montado e um vizinho que freqüentasse a antiga casa poderia agora ser estimulado a vê-la com outros olhos. Entretanto, nada, na situação anterior o teria impedido de também perscrutar a casa, para entendêla. Nada, portanto, de essencial o museu teria acrescentado, salvo a novidade de uma ocasião. Não é pouco. Mas está longe de ser tudo. Não basta, pois, montar um period room ou uma casa inteira, no estado original: isto é apenas o começo de um longo caminho.

Valeria a pena ainda examinar, em pormenor, as principais insuficiências e distorções desta modalidade de recontextualização. Em primeiro lugar, ela congela arbitrariamente, num de seus vários contextos, objetos que têm histórias, trajetórias (Kopytoff 1986). O ideal seria dar conta dessa dimensão biográfica, que representa a mobilização dos objetos para produção dos diversos estratos de sentido que podem ser historicamente levantados: o sentido "verdadeiro" da Mona Lisa não é o de seu contexto original de produção, nem - de qualquer outro contexto individualizado (fruição, musealização), mas as diversas superposições de sentido que referenciam sua trajetória histórica, do Renascimento até sua projeção no mundo da publicidade e da indústria cultural. No próprio campo da História da Arte, por exemplo, têm-se avolumado as tentativas de denunciar a insuficiência de imobilizar, num momento idealmente original, os significados da obra (Bryson 1991: 72). Obviamente, do ponto de vista da exposição, a possibilidade objetiva de abarcar aspectos tão amplos de problemas e capitalizá-los na exposição raramente estará presente. Acresce que, no estado atual, pouco sabemos como trilhar essa direção. Seja como for, é inadmissivel fazer acreditar um estrato como exclusivo. Arte negra é coisa de negro ou de branco? É apenas um jeu de mots dizer que é coisa de branco, pois é coisa de negro e de branco, em nosso mundo. Salvo quando a arte ocidental for exibida na África em museus etnográficos...

Em segundo lugar, o conceito de contexto em causa ignora que o processo de transformação do objeto em documento lque é, afinal, o eixo da 
6. Conviria reproduzir as próprias palavras de Pearce (1992: 141): "Material is transformed by the collecting process into a museum collection archive, and clearly it is transformed again as a further stage in the same sequence by the exhibition process. (...) The exhibition (and of course any succeeding exhibitions, and the publication and poster material which may accompany them) is the final element in this chain. It bears a metaphorical or symbolic relationship to all that preceded it and this is implicit in the idea of performance, but it retains its integral link with past reality through its display of real material, and this is the essen$\propto$ of its actuality". musealizaçãol, introduz referências a outros espaços, tempos e significados numa contemporaneidade que é a do museu, da exposição e de seu usuário (também algo que as irmãs Comte não chegaram a perceber).

Susan Pearce (1992: 139) caracterizou, com bastante propriedade, valendo-se da terminologia lingüística saussureana, essa perpétua criação de sentido, que se vê no museu e que se recicla conforme o seguinte esquema: um museu de Antropologia, por exemplo, toma a cultura material de um grupo (no sentido de evidências materiais observáveis/ como repertório, conjunto de possibilidades características socialmente disponiveis (langue, para Saussure); daí seleciona elementos que constituirão sua coleção (atualização do potencial da langue, portanto, parole l; a coleção, por sua vez, funciona novamente como repertório (languel que será acionado como parole na exposição ${ }^{\circ}$. Esta complexa rede não é gratuita. Deve servir, fundamentalmente, para prevenir o museólogo contra as ilusões e burlas da contextualização e cenarização que ele pode indulgentemente construir.

Finalmente, e mais importante que tudo, a reprodução de contextos que são pura aparência inverte o papel da exposição na produção de conhecimento: ao invés de partir destas relações aparentes para romper a unidade superficial daquilo que é apenas empiricamente verificável, sensorialmente apreensivel, a fim de encontrar linhas de unidade mais profunda e substancial lembora não sensorialmente perceptíveis, mas visualizáveis na exposiçãol, ao invés deste esforço crítico e criativo, a exposição termina aí, reforçando aquilo que a ação imediata dos sentidos já havia fornecido, mascarando as articulações invisiveis, porém determinantes. Estas considerações se inspiram em Alberto Cirese que, com muita autoridade, dirigiu severa e radical crítica à confusão, nos museus folclóricos italianos, do "vivo museográfico" com o "vivo real": "la vita di un museo stà nel ricostruire al proprio livello, disponendo il reale secondo linee di intelligibilità che il reale non ci presenta nella sua immediatezza" (Cirese 1977: 491. Sem reconstrução abstrata (que abstraia o sensorial, para chegar às matrizes) e sem análise, todo contexto é um logro.

A raiz destes modismos todos está na permanência de um realismo ingênuo, que ainda domina as práticas museológicas e cuja ruptura, como adverte Néstor García Canclini 11989: 1891, é impositiva e urgente:

"Así como el conocimiento científico no puede reflejar la vida, tampoco la restauración, ni la museografía, ni la difusión más contextualizada y didáctica lograrán abolir la distancia entre realidad y representación. Toda operación científica - pedagógica sobre el patrimonio es un metalenguaje, no hace hablar a las cosas sino que habla de y sobre ellas. El museo y cualquier política patrimonial tratan los objetos, los edificios y las costumbres de tal modo que, más que exhibirlos, hacen inteligibles las relaciones entre ellos, proponen hipótesis sobre lo que significan para quienes hoy los vemos o evocamos".

O exemplo atrás ilustrado, que propõe uma exposição sobre o tempo como fator de organização social no espaço urbano, mobilizando objetos de vária natureza em torno de um problema-chave, também pode servir para demonstrar a viabilidade de estabelecer contextos que, ao invés do 
trompet'oeil museográfico, funcionem como catalisadores de questões esparsas, não aparentes, invisíveis - mas dotadas de força geradora. Dessa forma, ao invés de passiva e preguiçosamente se reproduzirem os possiveis cenários de aparência para cada um dos tipos de objeto em causa (relógios de rua, equipamentos de iluminação e objetos descartáveis|, foram desmontadas as relações primárias, deixando subirem à tona outras relações latentes, mas fundantes. A solução empregada recusa acreditar que expor seja exibir objetos, na sua aparência individual ou nas relações aparentes. Pelo contrário, "exposer, c'est disposer de façon à manifester et à faire saisir les rapports, cet ordre sous-jacent qui est posé comme révélateur de la nature du réel en question" (Monpetit 1990: 13).

"living museum"

A advertência de Cirese e García Canclini pode ser aplicada a um dos casos particulares de reconstrução e contexłualização históricas que estão na moda, despertando entusiasmo cada vez maior e se apresentando como panacéia para solucionar todos os problemas e carências do museu histórico. Por isso, devemos prosseguir na análise do problema da contextualização pela ótica do chamado "living museum".

O "living museum" veio para decretar a morte do museu histórico tradicional: "...traditional history, and in particular the traditional methods of portraying history in indoor museums is dead; that is, dull and uninteresting, requiring too much intellectual effort and imagination on the part of the visitor " (Burcaw 1980: 5; G. Ellis Burcaw é um moderado simpatizante do movimento).

As expressões inglesas "Living History" e "living museum" traem a importância deste conceito para a Inglaterra e, mais que tudo, os Estados Unidos, embora a difusão seja hoje universal e tenha até começado a chegar até nós. Esta modalidade, essencialmente de exposição, se desenvolveu a partir do modelo dos museus ao ar livre, cujo referencial imediato é o museu criado em Skansen, na Suécia, por Artur Hazelius, nostálgico de um estado de coisas que a industrialização vinha apagando. Entreianto, suas origens mais longínquas podem ser localizadas em ambientes aristocráticos setecentistas, como a reprodução lúdica de uma aldeia camponesa, de Maria Antonieta (completa, incluindo leiteria em mármore), ou as folies do Parc Montceau ou os landscape parks da nobreza britânica (Wallace 1985: 40).

Começou-se com a reprodução de edifícios, espaços e objetos, chegando-se a estruturas complexas, como cidades inteiras |tal é o caso de Colonial Williamsburg, na Virginia, EUA). Terminou-se com a reprodução de situações e ações, com a completa teatralização da exposição (Anderson 1984, 1985, Leon \& Piatt 1989, Wallace 1989, Wilkinson 1993). Já no Museu de Skansen havia músicos ambulantes e dançarinos folcóricos, exibindose pelas ruas. Em outros museus, há os chamados third person interpreters que, vestidos a caráter, funcionam como guias - condição em que, por exemplo, podem aparecer fabricando velas com tecnologia e materiais antigos (as quais serão depois vendidas, obviamente a preços atualizados) ou ministrando aulas de música em cravos originais ou reproduzidos. Em Mystic Seaport, 
Connecticut, estaleiro do século XIX, os guias, em roupas modernas, demonstram técnicas de fabricação, por exemplo, de barris. Em Old Sturbridge Village, no Massachusetts, estabelecimento rural dos séculos XVIII-XIX, os técnicos em zootecnia procuraram até mesmo reconstituir características biológicas dos plantéis antigos (receio que carrapatos ou pragas do gado tenham sido anacronicamente excluídos desta regressão genétical.

Mas há também os first person interpreters, que despertam maior emoção, por dramatizarem, num ambiente que comporta também plantas e animais vivos, a vida cotidiana de certos contextos. Não agem como guias, mas como "talking exhibit labels" (Burcaw 1980: 5). Em Plimoth Plantation, Massachusetts, há intérpretes que vão ao limite de encarnar personagens individualizadas, por exemplo, entre os peregrinos do Mayflower - o que não tem deixado de provocar eventuais traumas, por ocasião do regresso ao século XX, ao final do expediente, conforme o testemunho de Burcaw 11980: 5).

Para uma apreciação crítica dos objetivos, procedimentos e ideologia da "Living History", vale a pena considerar um prospecto do Museu de Timbertown, cuja atenção se volta para uma comunidade de madeireiros do norte de New South Wales, na Austrália:

\begin{abstract}
"Step back into the past... and take a stroll through Australia's history. Timbertown is an entire village, re-created to demonstrate the struggles and achievements of our pioneers. It reflects the way they lived, the way they worked, their hardships and their skills. It is not a lifeless museum... It lives! It is an authentic, vital township where the stream train runs, timber is still sawn, the bullock team still trudges with its heavy load, the woodturner transforms natural timber into works of art, and the general store sells home-made wares and lollies in glass jars... Hear, too, the noises of yesteryear... the whistle of the steam train, the bellowing of the bullocks, the clanging of the blacksmith's iron. And, as you pass the old hotel, you hear the sound of the pianola or true Australian folk music, the happy sounds that entice the folk of the village into the tavern for a hearty singalong... Timbertown... a fascinating reflection of how people lived and worked in the simplicity and ruggedness of XIXth Century Australian bushlife" lapud Bennetf 1995: 158).
\end{abstract}

A primeira observação deve dirigir-se à própria noção de passado que esse museu histórico utiliza: é um pasado com substância em si, capaz de ser diretamente abordado, sem outras mediações (basta haver condições materiais), reprodutível no presente, resgatável, portanto um conjunto de fatos 'reais'. Tem-se, pois aquela convicção realista, cuja ideologia Claude lefort duramente combateu e cuja ilusão é presumir que "fatos se produzem em data e lugar determinados e são o que são enquanto esperam vir a ser conhecidos; e ainda, que se transformam de fatos 'reais' em fatos de conhecimento quando a eles se reporta um observador que se tornou capaz de apreendê-los sem nada projetar na sua superfície das paixões que o habitam" (Lefort 1979: 256-7). O conhecimento, então, segundo o autor, "encontra seu modelo na convicção segundo a qual aquilo que foi possuía em si sua identidade' (ib.: 257). 0 "living museum" atualiza, quase um século depois, o ideal rankiano de História ("wie es eigentlich gewesen"). 
Além de reificar o passado, Timbertown propõe uma atitude também inconsistente: não um caminho sensorial para a apreensão histórica lo Theatrum Historiae de que falava Eilean Hooper-Greenhill), mas uma apreensão exclusivamente sensorial. O visitante capaz de "stepping back into the past" se incompatibiliza, por isso mesmo, com o conhecimento, pois se anulam as distâncias, num processo de banalização e pseudofamilarização, que transforma o passado na mesma substância que o presente, apenas com diferenças, pois se trata de um presente anterior. É o mesmo passado do retrato de família, em que se fundem diversas gerações, cada uma com seus traços diferenciais, representando tempos distintos (anterioridades, posterioridades), mas tudo amalgamado pelo mesmo espaço da reunião. Este procedimento é profundamente antipedagógico, pois nós aprisiona no presente $e$, incapaz de nos fazer compreender a alteridade no que ela tem de específico, transforma esse presente no único termômetro capaz de tudo medir. A apreensão do passado, ao contrário, exige a apreensão do que David Lowenthal (1985) chama de "pastness of the past", num livro significativamente intitulado The past is a foreign country. Esta "Mickey Mouse history", na expressão de Wallace (1989) só pode ter como efeito a "disneyficação" do passado. Ou, para abordar a questão mais tecnicamente, o congelamento do passado, por exemplo em Colonial Williamsburg, onde tudo parece recém-saído do forno, sem variação de ritmos e sem ação visível do tempo, conduz a um vedadeiro exorcismo da História: "esses prédios e objetos não parecem vir de nenhum passado, mas antes de um eterno presente. O desaparecimento da 'aura', de que nos fala Benjamin, parece aqui ter atingido um limite extremo" (Gonçalves 1988: 271).

Uma terceira questão diz respeito ao fato de os "living museums" se vangloriarem da introdução de temas democráticos no reduto aristocrata do museu histórico: povo e cotidiano. O povo é um conjunto de estereótipos, necessários para o funcionamento do modelo, heroicizado, idilizado como convém a pioneiros e fundadores. O colidiano, por sua vez, é apenas uma enciclopédia de "ações típicas", atemporais, a-historicizadas, liberadas de qualquer estrutura ou sistema. Parece até que o cotidiano deixou de ser o locus de instituição e produção efetiva das relações sociais. Não há conflito, tensão, apenas "vida", que se concebe, é claro, de maneira puramente cinética: "it lives!". Ao inverso, uma exposição sobre o cotidiano seria histórica quando, além de "mostrar como se vivia", fosse capaz de explicar porque se vivia assim. Não é o caso, aqui.

Mais grave que tudo, a teatralização reforça a ilusão de que conhecimento e observação (percepção sensorial) se recobrem. E o faz com sedutora e perversa força de conviç̧ão, como se pode ver do depoimento inequívoco de um visitante de um dos "discovery corners" da Exposição do Bicentenário no National Museum of American History, Washington, em 1976: "Here you can see history, the way things look, the way it must have been. Seeing it makes you believe it happened" lapud Carson \& Carson, $1983: 1871$. 
Ninguém, em sã consciência, poderia desmerecer os benefícios da experimentação possível nas ciências humanas, para resolver e aprofundar problemas de conhecimento (como é o caso, por exemplo, da arqueologia experimental que criou critérios sólidos para simulação e replicação da produção e uso de artefatos e contextos; cf. Archéologie expérimentale 19911. Nem para fins pedagógicos, por intermédio da dramatização que, ao propiciar a experiência de assumir a persona de outrem, abre um leque de indagações e percepções. Em suma, a encenação da História pode constituir apreciável estímulo para o conhecimento; nunca, porém, deveria ser confundida com o conhecimento a produzir, ele próprio (Kavanagh 1986). Esta linha demarcatória a "Living History", inebriada por seu sucesso, etá ainda muito longe de traçar.

A "Living History", é preciso que se diga, é fruto de uma sociedade que, dos meios de comunicação de massa à publicidade e à presença difusa do mercado, se caracteriza pelo poder conservador de transformar o ver em crer" (De Certeau 1980: 312 ).

Já há algum tempo que esse oculocentrismo vem sendo objeto de crítica cerrada, não só por suas fraquezas epistemológicas, mas também por seus comprometimentos sociais e políticos em virtude das implicações da hegemonia da visão no "regime escópico" que gerou a vigilância onipresente e a espetacularização da vida. Martin Jay (1993), ainda que centrado na filosofia francesa deste século (Sartre, Merleau-Ponty, Foucault, Lacan, Althusser, Debord, Irigaray, Levinas, Derridal, cobre, com profundidade, o processo instaurado contra esse "mais nobre dos sentidos". Já a antologia de David Levin (ed. 1990) faz o mesmo, incluindo Gadamer, Wittgenstein, Habermas, Heidegger, Husserl, Nietszche, Hegel, Descartes, Platão.

Em particular, interessa-nos, aqui mais de perto, o problema da "sociedade do espetáculo", título da obra de Guy Debord, aparecida originalmente em 1967 e que, mesmo tendo perdido seu impacto original e se ressentindo de algumas generalizações apressadas e intolerantes, permite examinar questões pertinentes. Seu ponto de partida é que "toute la vie des sociétés dans lesquelles règnent les conditions modernes de production s'annonce comme une immense accumulation de spectacles" (Debord 1992: 3). Tratando da questão como aspectos da reificação e do fetichismo, Debord, referindo-se ao consumo, tece considerações que se ajustam perfeitamente às exposições da "Living History":

"Le spectacle, qui est l'effacement des limites du moi et du monde par l'écrasement du moi qu'assiège la présence-absence du monde, esł également l'effacement des limites du vrai et du faux par le refoulement de toute vérité vécue sous la présence réelle de la fausseté qu'assure l'organisation de l'apparence. Celui qui subit passivement son sort quotidiennement étranger est donc poussé vers une folie qui réagit illusoirement à ce sort, en recourant à des techniques magiques. La reconnaissance ef la consommation des marchandises sont au centre de cette pseudoréponse à une communication sans réponse" (ib. 167).

"living museum" bem caracteriza o vazio a que pode conduzir uma intenção superficial de comunicação. Hans Haacke, numa crítica virulenta a Baudrillard, diagnostica como sua condescendência com o simulacro é que o levou, assim como a seus discípulos, a perderem o sentido da História e dos 
conflitos sociais, engolfando-se no êxłase da comunicação, em estado quase místico (Bourdieu \& Haacke 1995: 46).

Exposição e discurso.

Tem-se dito, muitas vezes, que a exposição é um discurso ou, mais precisamente, um "texto". Aquilo que é a monografia, no domínio da palavra escrita, seria a exposição ("monoplastia"?) no domínio dos objetos - o que, todavia, não pode equivaler a transformar a exposição num trabalho acadêmico. Seja como for, a exposição, na linha aqui desenvolvida, pressupõe a articulação de enunciados sobre certos problemas humanos, desenvolvidos com o suporte das coisas materiais.

Não é o caso de entrar, neste texto, no que seja a exposição museológica à luz da Semiótica, pois a digressão seria longa e espinhosa, em razão do terreno movediço e lacunoso, particularmente quando o enfoque parte da História. Por isso, restrinjo-me a apontar as implicações, para uma exposição, da aceitação do caráter discursivo do objeto de museu - tema que já foi apontado acima.

Edwina Taborsky, examinando o problema da visualidade numa perspectiva mais restrita que a que se acabou de apontar, mas associada de forma imediata à problemática dos museus, e comparando o paradigma discursivo e o observacional, conclui que este último é que impera soberano nos museus, privilegiando as singularidades do indivíduo e do objeto e presumindo (como foi denunciado acima), a existência de uma "mensagem" que se moveria, intacta, ao longo do espaço e do tempo. Apesar de arraigado, tal paradigma não encontra hoje muito elemento de sustentação: "modern analysis of cognitive action is saying that this is not how meaning arises... The meaning of the object only becomes existent in an interaction between observer and object" (Taborsky 1990: 69). Na mesma trilha, Roger Silverstone aponta como - significado de um objeto ou de uma exposição depende significativamente de um "curatorial work of the visitor in which objects are reinscribed into a personal culture of memory and experience" (Silverstone 1994: 165).

É preciso reconhecer, porém, que estamos longe de poder incorporar noções como a de objeto discursivo à prática museológica e, sobretudo, museográfica. Nem mesmo há interesse suficiente para discutir os inúmeros problemas teóricos, metodológicos e operacionais envolvidos. Por essa razão, discurso e texto (monografia) serão tomados aqui apenas com sentido analógico. Tal analogia servirá para salientar dois pontos importantes, em que valeria a pena aprofundar a semelhança e a dissemelhança entre exposição e monografia. A semelhança desejável está no encaminhamento argumentativo e aberto da monografia (penso, especialmente, no domínio das ciências humanas e sociais): ela vale pela força de seu referencial los documentos que seleciona e processa, a "construção" em suma, de um sistema documental, que deve ser justificado) e de seus argumentos (que derivam de opções teórico-metodológicas também a exigir justificatival; além, é claro, da relevância e pertinência dos problemas em foco. Tal postura deveria implantar-se, semelhantemente, no campo das exposições, embora haja a barreira dos hábitos consolidados e o 
desconhecimento das possibilidades museográficas. Mas por que a exposição, ao contrário da monografia assinada, se desobriga de colocar à vista as cartas que montaram seu jogo? $E$ por que não introduzir na exposição (e não apenas, eventualmente, no catálogol seu caráter contingente e não absoluto, definitivo?

A dissemelhança básica a ser ressaltada, entre exposição e monografia, está em dois níveis. $O$ primeiro é que, numa monografia, os documentos (significantes), uma vez explorados na produção de significados, podem ser dispensados, sem precisar servir de suporte, como na exposição, para formular (e comunicar) esses mesmos significados. Esse duplo papel dos objetos na coleção e na exposição tornam esta última uma operação consideravelmente mais complexa do que a redação de um texto. Seu potencial cognitivo-afetivo, entretanto, é muitíssimo mais desenvolvido.

O segundo nível diz respeito à especificidade da linguagem museológica, que é essencialmente espacial e visual - não simples variação ou adaptação da linguagem verbal. Mais uma vez, é o despreparo no enfrentamento do objeto que, na exposição, pressiona um lamentável deslocamento de papéis: o que deveria ser "dito" com os objetos passa à responsabilidade das legendas e outros recursos, como os audiovisuais e eletrônicos (v.acima, p.29). Neste caso, o museu é dispensável e deveria ser substituído por instrumentos mais eficazes.

\section{História e museu histórico: o laboratório da História}

Depois do longo caminho percorrido, ainda há questões cruciais que necessitam ser retomadas.

"Pode-se expor História em museu?" com esta pergunta, Hartmut Boockmann (1987), historiador encarregado de projetar o Museum für Deutsche Geschichte, abre um livro cujo título é outra pergunta: Geschichte im Museum? Sua resposta admite problematicamente a História no museu, desde que não seja para alimentar um manual tridimensional, ou, solução ainda mais inepta, o manual de parede.

Com preocupação paralela, seus colegas Jörn Rüsen, Wolfgang Ernst e Heinrich Theodor Grütten (eds. 1988) organizam uma coletânea de trabalhos subordinados a um título de teor comparável: Geschichte sehen, 'Ver a História'. Alguns destes textos tratam do problema epistemológico; outros, na linha do subtítulo (Beiträge sur Ästhetik historischer Museen ) aludem à presença e função do estético no museu histórico e, até mesmo, à documentação visual na pesquisa histórica.

As perguntas que estas obras introduzem são de fato as perguntas decisivas. A luz do que foi dito até aqui, é possivel apresentar respostas definidas.

Não, a História não pode ser visualizada. A História não é algo que possa ser apreendido sensorialmente - modo padrão de estímulo na exposição. Exclui-se, portanto, da responsabilidade do museu histórico preservar ou restituir o passado - quaisquer que sejam as motivações. Tudo que se fizer nessa direção estará, inelutavelmente, permeado de ideologia e mascaramentos. 
Sim, a História, forma de conhecimento, tem lugar assegurado no museu histórico. Aliás, há domínios históricos /vinculados à problemática da cultura materiall, que a História não poderia desenvolver ou desenvolveria de forma precária, sem a contribuição do museu. $\bigcirc$ museu histórico coleta, preserva, estuda e comunica documentos históricos. A exposição verdadeiramente histórica é aquela em que a comunicação dos documentos, por sua seleção e agenciamento, permite encaminhar inferências sobre o passado - ou melhor, sobre a dinâmica - da sociedade, sob aspectos delimitados, que conviria bem definir, a partir de problemas históricos ${ }^{7}$. Inferências são abstrações, que não emanam da materialidade dos objetos, mas dos argumentos dos historiadores, referindo-se a propriedades materiais "indiciárias" desses objelos e a informações sobre suas trajetórias.

Nesse horizonte, a gumas diretrizes podem ser sugeridas:

1. O museu histórico não é compatível com sínteses (independentemente da pertinência, ou não, hoje em dia, de uma "História Universal", ou de "histórias nacionais"). Exposições dessa ordem serão sempre panoramas alegóricos que, além de todos os inconvenientes das sínteses, não passarão de manuais tridimensionais, tão renegados por Boockmann. A possibilidade de estimular a "absorção de informação" pode ser uma justificativa, ainda que frágil, para łal tipo de exposição. Sua presença exclusiva, porém, não justificaria a existência de um museu histórico. Estas observações valem, também, para panoramas regionais ou locais.

2. A História não pode ser explicativa fora de quadros como as estruturas. Embora não esteja no alcance da exposição histórica representar estruturas, a representação de aspectos estruturais em funcionamento é possivel, nem que seja pelo fato de os objetos não atuarem autonomamente, mas participando de sistemas. Segundo o testemunho de Bennett (1988), o People's Palace de Glasgow conseguiu dimensionar adequadamente aspectos da vida cotidiana, ao cruzar, numa mesma exposição, diversos sistemas que se articulavam (como esportes, política, vida doméstica, etc.). Esta linha analítica comparativa também pode ser apreciada no Nordska Museet de Stockholm (Kavanagh 1986: 176) e em mais um punhado de museus.

3. Objetos não podem tampouco representar processos, dinâmica social, etc. Mas podem ser exibidos como vetores desses fenômenos. Assim, o estudo do sexo dos objetos (que suas propriedades empíricas fundamentam), não numa perspectiva psicanalítica, mas social, permite exibi-los a serviço da demarcação e indução de papéis sexuais, portanto, da distribuição de obrigações, direitos e privilégios e segundo padrões que se transformam continuamente.

A exposição dos diversos tempos dos artefatos (discerniveis nas defasagens de natureza tecnológica, morfológica, funcional, semiológica) permite tratar -visualmente - dos diversos tempos sociais e suas imbricações.

4. Enfim, do ponto de vista metodológico (base também para uma sólida exploração educacional), as possibilidades da exposição histórica são privilegiadas. Não sendo a História um conjunto a priori de noções, afirmações e informações - mas uma leitura em que ela mesma institui, em última instância, aquilo que pretende tornar inteligível - ensinar História só pode ser,
7. O Museu Paulista da USP, por exemplo, definiu como problemaschave para articular sua atuação (tomando como corte cronológico prioritário o período que vai de 1850 a 1950): a. Coti diano e scciedade: trata-se de entender como os objetos, principalmente no espaço doméstico (mas também, p.ex., na educação e outros contextos associados), nâo só respondem a funçôes utilitárias, mas, em última instância, classificam as pessoas, fornecem modelos e geram critérios e condiçôes para as relações sociais, b. Universo do trabalho (pré- $\mathrm{e}$ proto-industrial): 0 objetivo não é apenas documentar descritivamente campos que por certo terâo que estar presentes, como as atividades e contextos materiais das diversas categorias de artesãos e trabathadores, mas, sobretudo, extrair dos objetos de todos os acervos o que eles representam, não apenas como resultado de trabalho, mas como trabalho embutido, materializado. $c$. Imaginário da Histốria: as coleções de imagens do Museu são muito ricas, por causa de seu papel original de memorial. Seria pueril apenas procurar identificar nas figuras e cenas de heroismo histórico, mentiras históricas e desmascará-las. Trata-se, antes, de tomar o mito histórico, as visualizaçôes da História, de seus agentes, contingências e produtos, como parte do imaginário social - a 
outra face indissociável da prática social - e analisá-los historicamente. Aqui entra também o comportamento do público, que caracteriza o que os historiadores denominam de "religião cívica" (Richey \& Jones, eds. 1974, Bellah 1975, Kammen 1991: passim e especialmente 194227). obrigatoriamente, ensinar a fazer História le aprender História, aprender a fazer História). Por isso, a diretriz lobviamente não exclusiva, mas necessariamente presente) de um museu histórico seria transformar-se num recurso para fazer História com objetos e ensinar como se faz História com os objetos. Esta postura abre horizontes para infinitas possibilidades expositivas. Assim, numa mostra, suponhamos, sobre a Revolução Constitucionalista de 1932, não se deveria procurar a "versão" mais "correta" ou "adequada ao estado da disciplina", pois isso será sempre feito melhor e com muito maior competência numa monografia. Antes, do museu esperase que acompanhe como uma revolução se transforma em memória e, nesse processo, qual o papel desempenhado pelos objetos: como uma revolução vira coleção. Reitere-se o que já se afirmou: ao museu não compete produzir e cultivar memórias, mas analisátlas, pois elas são um componente fundamental da vida social. E como esta memória é multifacetada e socialmente localizada (dos combatentes em ambas as trincheiras, das mulheres e das crianças, dos políticos, dos fabricantes de armas e dos comerciantes, dos historiadores e literatos, dos tecnólogos e banqueiros e assim por diante), a exposição não deveria manter-se unilinear. Para tecer um texto espacial com todas estas variantes, a História Oral poderia também colaborar. Penso, ainda, até mesmo em outras possibilidades extraordinárias, que encontram paralelo em experimentações na História escrita, com narrativas a várias vozes (Burke 1992). Assim, por que não organizar duas exposições paralelas explorando o mesmo tipo de material, mas chegando a pontos divergentes? $\bigcirc$ objetivo não seria relativizar o conhecimento histórico, mas demonstrar quais seus ingredientes e processos construtivos e, portanto, medir seu alcance.

Este filão, aliás, parece que vai sendo descoberto pelos museus que postulam uma abordagem crítica ou, como propõem Karen Davis e James Gibb, que procuram substituir o marketing pela responsabilidade social, isto é, tornarem-se responsáveis "for equipping people to explore the past critically and for helping them apply those skills to the criticism and interpretation of contemporary society" (Davis \& Gibb 1988: 44). Vários exemplos alvissareiros podem ser apontados. Elizabeth Sharpe (1987: 10) analisa exposições como Everyday Life in America, 1780-1800 e os respectivos espaços paralelos (Hands on History Rooms) destinados a introduzir à natureza e exploração das fontes materiais na produção do conhecimento histórico. Programas de mesmo objetivo são desenvolvidos no Hallockville Museum Farm, de Long Island, N.Y. (Davis \& Gibb 1988: 44). E uma coletânea de resenhas críticas a exposiçōes históricas recentes em museus americanos (Ames, Franco \& Frye, eds. 1992), apesar de altos e baixos, testemunha o surgimento da preocupação analítica e metodológica como requisito de rotina.

Se for possivel resumir num foco único o nervo de todas as reflexões até aqui acumuladas, diria que o fio condutor é a dimensão crítica da exposição. "Crítica" no sentido etimológico, que implica competência de distinguir, filtrar, separar, portanto, possibilidade de opção, escolha. Se o museu tem responsabilidades na transformação da socieade le a exposição, para tanto, é recurso fecundo), isto se fará não com procedimentos de exclusão elitista, ou catequese populista, mas na medida em que contribuir para 
capacitar nas escolhas todos aqueles com quem puder se envolver. Se o museu se eximir da obrigação de aguçar a consciência crítica e de criar condições para seu exercício estará apenas praticando uma forma mascarada do autoritarismo que os museólogos tanto têm exposto à execração.

Compensa relembrar a experiência não muito longínqua dos Centros Populares de Cultura, cujo Manifesto, de 1962, define o CPC como "órgão cultural das massas", "fruto da própria iniciativa, da própria combatividade criadora do povo", povo que deveria ser o "ator politizado da pólis", criado pela vanguarda político-cultural (para uma análise sem complacência, ver Chauí 1983: 63-92, especialmente 86 e ss.). Contudo, sabe-se que, à falta de investir na possibilidade de autodeterminação cultural, o que ocorreu foi a arregimentação popular para um projeto de infelectuais militantes. A lição é que o projeto político precisa ser essencialmente um projeto de sociedade em que os cidadãos, como sujeitos, tenham o direito e as condições de formular seus próprios projetos políicos.

Isto realça a importância visceral da formação crítica - a meu ver a responsabilidade maior do museu, como, aliás, de toda ação cultural:

"De um modo ou de outro, é pacífico que a ação cultural ou é uma operação sociocultural ou não existe. Mesmo assim, uma concepção mais radical da ação cultural, e acaso mais digna, é a que aposta na tese segundo a qual o objetivo da ação cultural não é construir um tipo determinado de sociedade, mas provocar as consciências para que se apossem de si mesmas e criem as condições para a totalização, no sentido dialético do termo de um novo tipo de vida, derivado do enfrentamento aberto das tensões e conflitos surgidos na prática social concreta (Coelho 1989: 42).

Desvinculado de obrigações científico-documentais, o museu se compromete, irremediavelmente, em todo seu enorme potencial.

É possivel, agora, voltar à imagem inicial do Theatrum Memoriae e propor que, se porventura se quiser apreender o sentido do que ali se passa, é recomendável dirigir-se ao Laboratório da História. Se o Teatro da Memória é um espaço de espetáculo que evoca, celebra e encultura, o Laboratório da História é o espaço de trabalho sobre a memória, em que ela é tratada, não como um objetivo, mas como objeto de conhecimento.

No museu, principalmente no museu histórico que superou a função de repositório e dispensador de paradigmas visuais, a inteligibilidade que a História produzir será sempre provisória e incompleta, destinada a ser refeita. Daí, porém, sua fertilidade. Por isso tudo, talvez o museu histórico já esteja maduro para fazer aquilo que só o museu pode fazer bem, com competência e por vocação (ainda não atualizada): explorar, não sínteses históricas sensoriais, mas a transformação dos objetos em documentos históricos. Em vez de teatro, laboratório, com tudo aquilo de criador que essa idéia contém. 


\section{Agradecimentos.}

A Márcia Medeiros de Carvalho e à Biblioteca do Museu Paulista da USP, por auxílio na obtenção de cópias xerox de trabalhos inexistentes em São Paulo; a Jaelson Bitran Trindade pelo encaminhamento do texto de José Mariano Filho; a Pedro Bezerra de Meneses Bolle, por solucionar problemas técnicos na digitação deste artigo. 


\section{RESUMOS / ABSTRACTS}

Do Teatro da Memória ao Laboratório da História: a exposição museológica e o conhecimento histórico

Ulpiano T. Bezerra de Meneses

O texto procura discutir as condições de produção e apropriação do conhecimento histórico a partir do momento em que o museu deixa de aceitar como seus objetivos a evocaçāo ou celebração do passado. São examinadas diversas premissas, na perspectiva dos conceitos da cultura material: o papel insubstituivel das coleçães e a necessidade de definir problemas históricos como balizas; a construçāo social do objeto histórico, diversa da construção epistemológica do documento histórico; a retórica da exposição museológica e o uso fetichista, metonímico e metafórico dos objetos, etc. A encenação histórica ("living museums"), a contextualização museológica, as instalações, etc., são criticamente analisadas, apontando-se seus benefícios, riscos e danos (com especial atenção são tratados o paradigma observacional de conhecimento e o realismo ingênvol. A seguir, consideram-se as implicações da História como um processo cognitivo discursivo, enfatizando-se a necessidade de se fixarem responsabilidades metodológicas para os museus históricos /como produzir entendimento histórico por intermédio dos objetos; como entender a sociedade na sua mobilização de objetos em sua busca de auto-imagem e inteligibilidade).

UNITERMOS; Museu histórico. Museu e conhecimento histórico. Exposição histórica. Objeto histórico. Encenação histórica Anais do Museu Paulista: N.Ser. v.2, 1994.

From the Theater of Memory to the Laboratory of History: museum exhibits and historical knowledge Ulpiano T. Bezerra de Meneses

The paper aims at discussing conditions for the production and appropriation of historical knowt edge, once a museum denies evocation and/or celebration of the past as its legitimate purposes. Several premises are surveyed within the general framework of material culture concepts: the irreplaceble role of collections and the need of establishing historical problems as basic guidelines; the social construction of the historical object as distinguished from the epistemological construction of the historical document; the rhetorics of museum exhibits and the fetishist, metonymic and metaphoric uses of objects etc. Living museums, museological contextualizations, installations etc. are critically analysed and their benefits, risks and mischiets assessed (special attention is assigned to the observational paradigm of knowledge and the biases of a naif realism). Implications of History as a discursive cognitive process are then considered, emphasizing the importance of setting up methodological responsabilities for historical museums (how to produce historical under standing through objects; how to understand society as it searches intelligibility and auto-image through objects).

UNITERMS: History museum. Museum and historical knowledge. History exhibits. Historic

object. Living museum.

Anais do Museu Paulista: N.Ser. v.2, 1994.

De morcegos e caveiras a cruzes e livros: a representação da morte nos cemitérios cariocas do século XIX

Tania Andrade Lima

Considerando que os espaços destinados aos mortos em uma sociedade refletem especularmente - mundo dos vivos, sendo ambos regidos pela mesma lógica de organização, os cemitérios foram entendidos como um lugar de reprodução simbólica do universo social, e, nessa condição, como um campo privilegiado para a análise do processo de implantação e consolidação dos valores burgueses na sociedade carioca do século passado.

O presente trabalho, considerando a ruptura do império escravista, na década de 1880, e a emergência de uma república progressivamente capitalista, voltou-se para a verificação de prováveis mudanças no imaginário coletivo sobre a morte, nos cemitérios do Rio de Janeiro, provocadas pelo rompimento da ordem escravocrata. Uma pesquisa foi conduzida no sentido de 